تحليل منطقهاى خشكسالى هيدرولوزيكى در حوضه آبريز آجى جاى با استفاده از شاخص RDI حجت احمدزاده '"، احمد فاخرىفرد'، محمدعلى قربانى' و مسعود تجريشى'

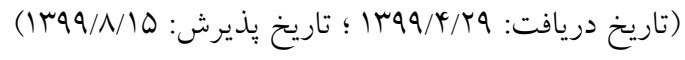

جكيده

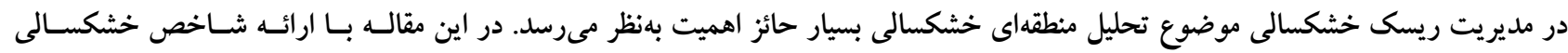

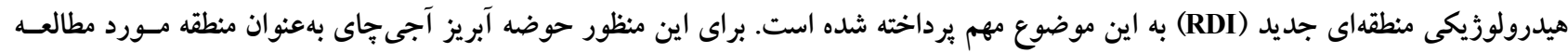

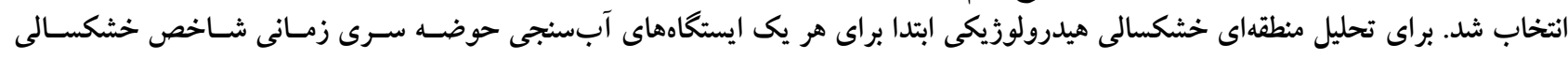

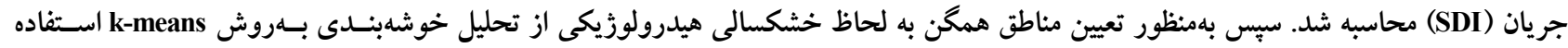

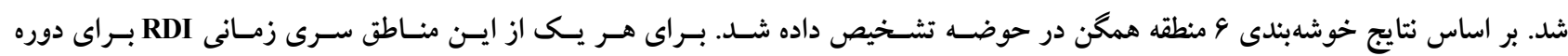

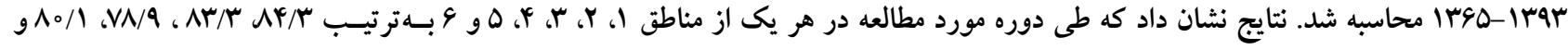

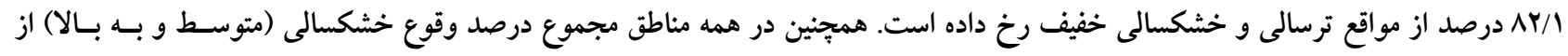

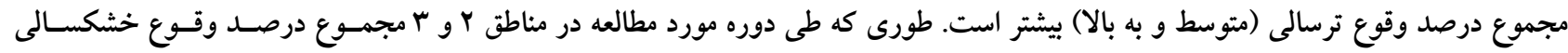

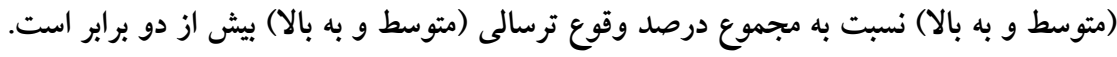

وازمهاى كليدى: تحليل منطقهاى خشكسالى، SDI، خوشهبندى، RDI، مناطق همخن، حوضه آبريز آجى جاى

1. كروه مهندسى آب، دانشكده كشاورزى، دانشخاه تبريز

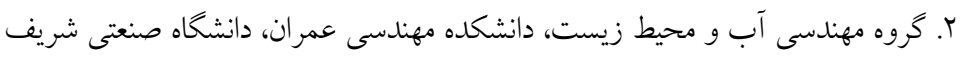
* مسئول مكاتبات: يست الكترونيكى: hojatahmadzadeh6@gmail.com مرنى 
ويزگى هاى مهم در رفتارسنجى اين بليه محسوب مىشـود و در

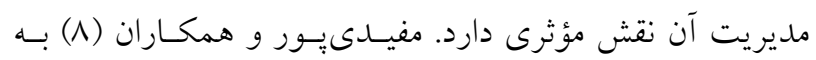

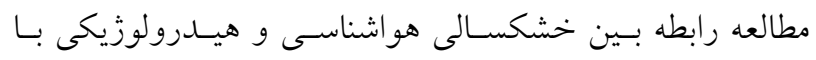

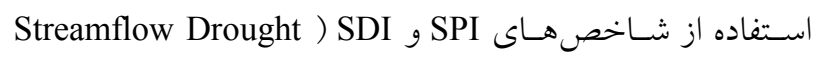
(Index

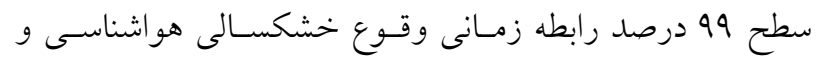
هيدرولوزيكى معنى دار بوده و اين همبستخى براى دوره م ماهـهـ حداكثر است. اسلاميان و همكاران (ه) با توجه به مفهوم دبسى هنى

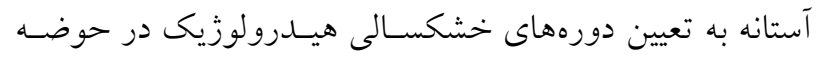

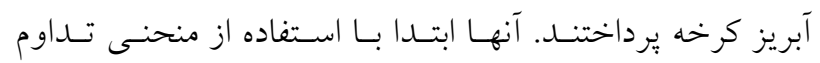

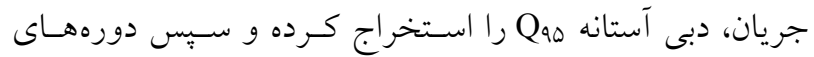

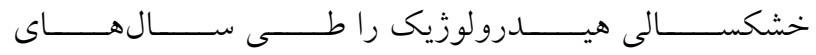

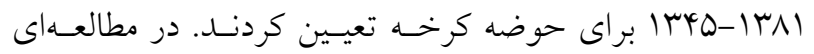

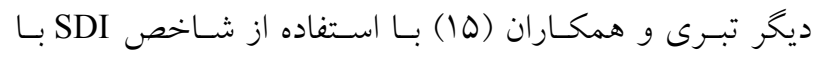

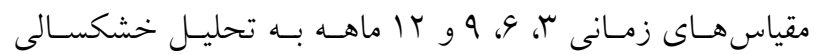

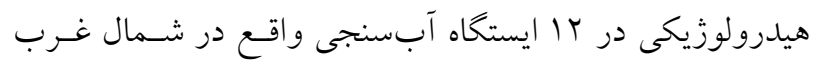

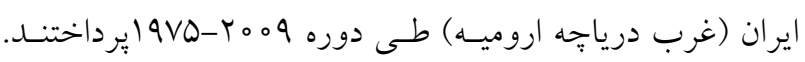

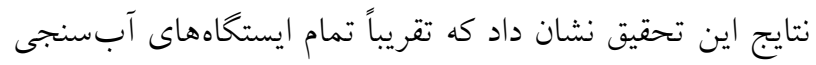

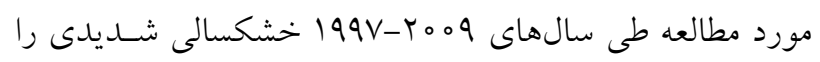
تجربه كردند. در زمينه خشكسالى منطقهاى مطالعـات كمتـرى نسـبت بـهـ خشكسالى نقطهاى صورت كرفته اسـت. اسـلاميان و همكــاران (9) به بررسى براكنش مكانى ويزّكى هاى خشكسـالى در استسان

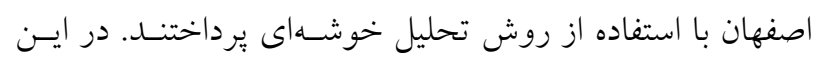
تحقيق با استفاده از ما مشخصه خشكسالى كه بر اساس شدت، مدت و فراوانى شاخص SPI سه ماهه استوار بودند و با استفاده

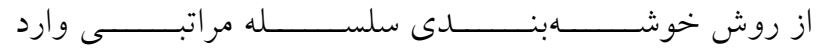
ينج گروه مكانى خشكسالى (Ward Hierarchical Clustering)

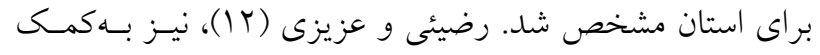

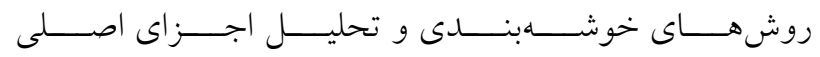
به منطقهبندى رزيم بارشى (Principal Component Analysis) در منطقه كوهستانى غرب ايران بر اساس ها يـارامتر اقليمسى

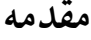

خشكسالى (Drought) يكى از مهم ترين و شايع تـرين بلايـاى جوى و اقليمى است كه بخش هاى مختلف جامعه مانند منـابع آب قابل دسترس، كشاورزى، صنعت، اقتصاد، بهداشت و... را

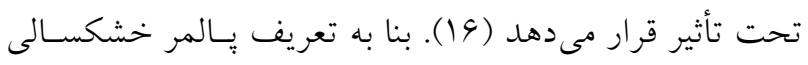

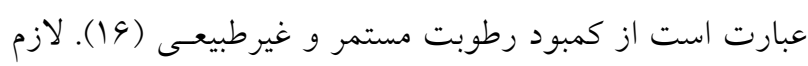

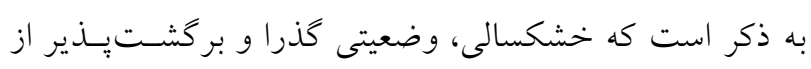

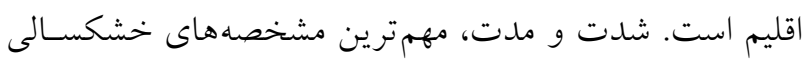

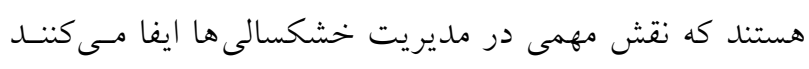

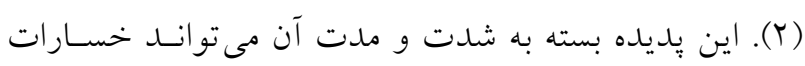

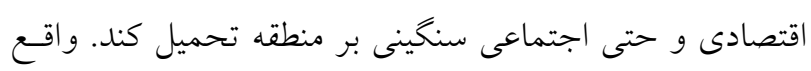

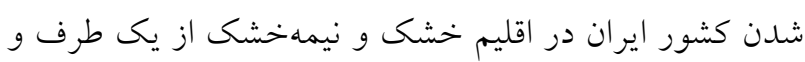

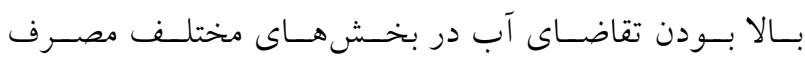

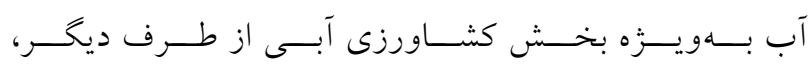

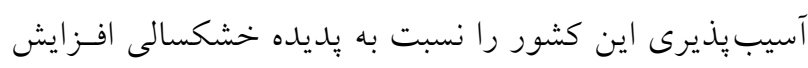

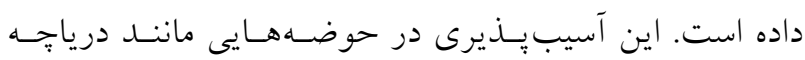

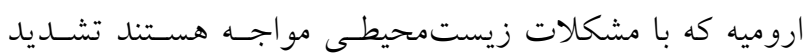

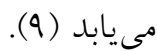

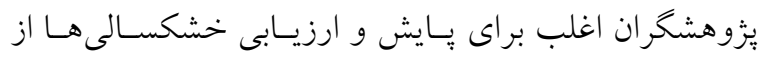

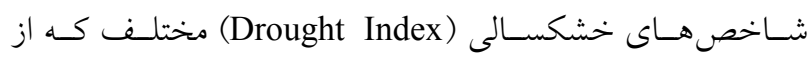
متغيرهاى هيدرولوزيكى، اقليمى، زراعتى مشتق شدهاند، استفاده

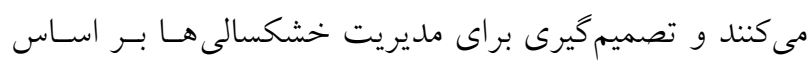

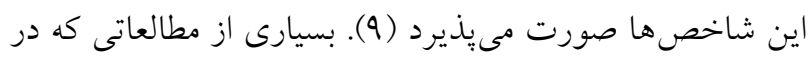

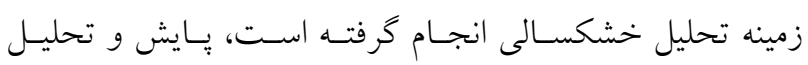
خشكسالى بلصورت ايستاهى (نقطهاى) صورت گرفته و نتايج

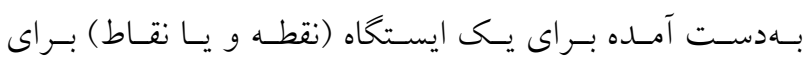

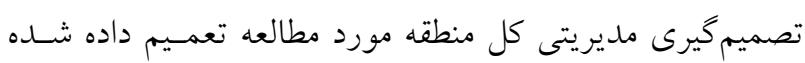

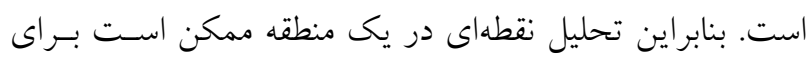

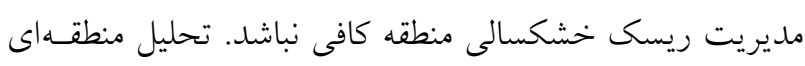

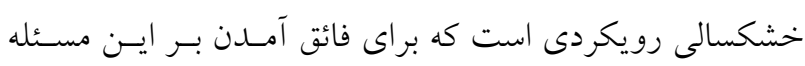

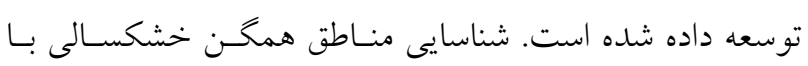

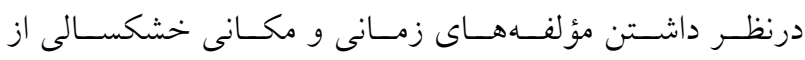


نو آورى و مزيت تحقيق حاضر را مىتوان كمى كـردن شـدت

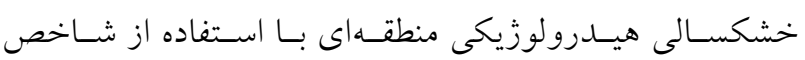
جديد RDI - ملقى كرد.

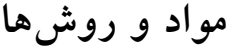

منطقه مورد مطالعه و دادهها

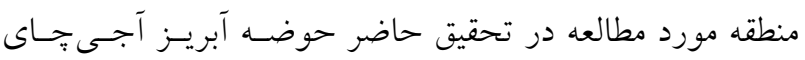

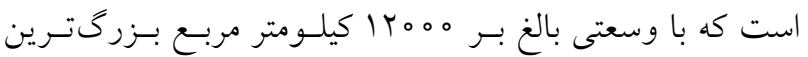

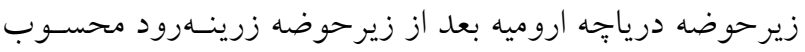

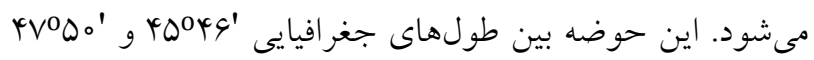

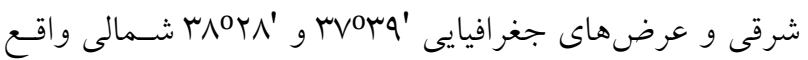

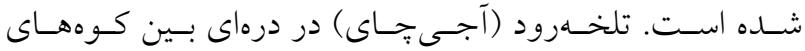
ارسباران غربى، قوشه داغ و سبلان از شمال و كوههاى برقـوش

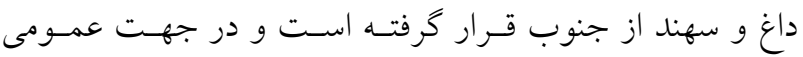
شــقى - غربسى جريـان دارد. طــول رودخانـه اصسلى حوضـهـ آجى جاى حدود له Y كيلومتر بوده و شهرهاى تبريـز، آذرشهر، سراب، بستان آباد، هريس و اسكو نقاط مهم شهرى آن بهشمار

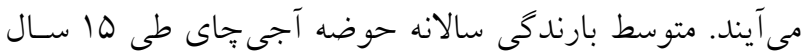

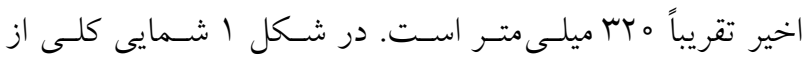

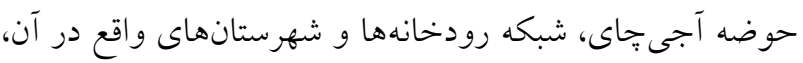

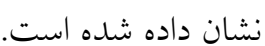

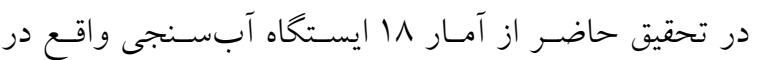

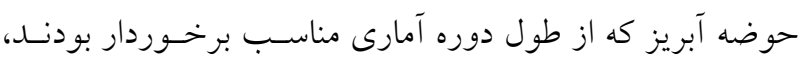
براى بررسى تحليل خشكسالى هيدرولوزيكى منطقهاى استفاده

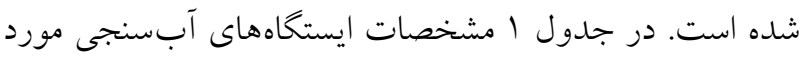
استفاده در تحقيق حاضر آورده شده است.

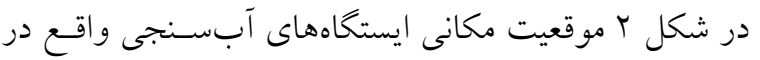

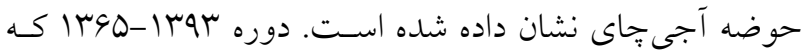
در آن همه ايستخاههاى آبسنجى مورد مطالعه در حوضه آبريـز

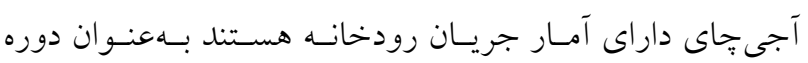

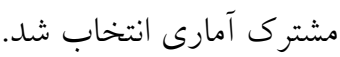

در IV0 ايستخاه هواشناسى ير اكنده در سطح منطقه برداختنـد.

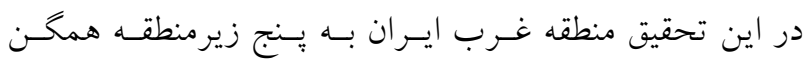

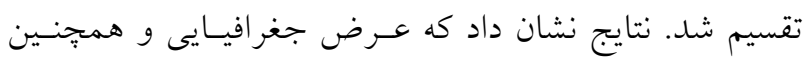
ناهموارى هاى موجود در منطقه در منطقهبنـدى رزيــم بارشى لهـ

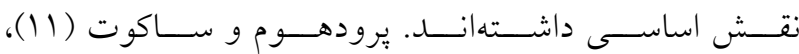
به بررسى خشكسالى منطقهاى در كشور فرانسه يرداختنــ. در

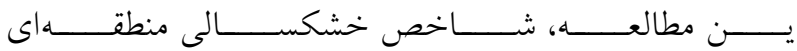
DI و خشكسـالى نقطـهاى Reginol Drought Index) RDI براى اين بررسى مورد اسـتفاده قـرار كرفتنـــ. از ضـففهـاى شاخص RDI در اين تحقيق اين است كه تنها وقوع و يا عـدم لمعرم وقوع خشكسالى منطقهاى را مشخص مى كند و هيج اطلاعاتى

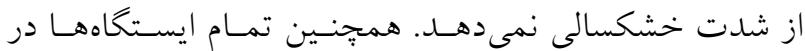

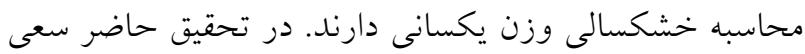
شده است كه اين ضعف ها مرتفـع شـود. سـنتس و همكـاران (rا) براى ارزيابى الخوى مكانى و زمانى خشكسالى در كشور

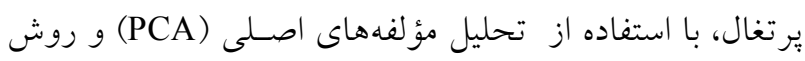

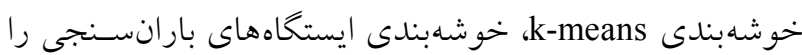
بر اساس شاخص هاى SPI يك، شش و دوازده ماهله به انجـام

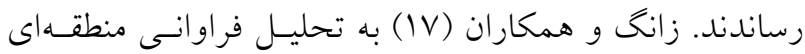

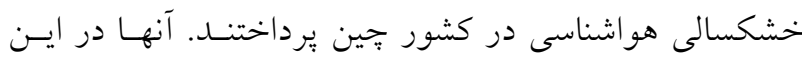

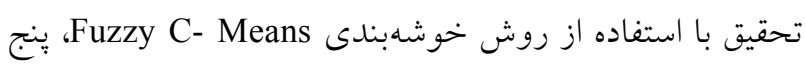

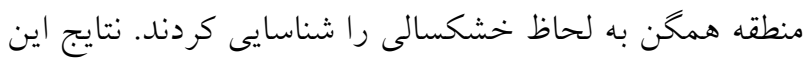

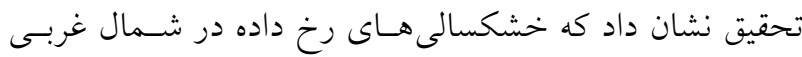

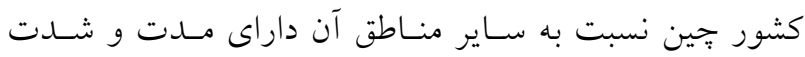

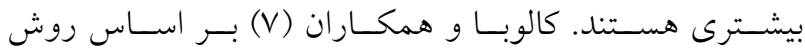
L-moments به تحليل فراوانى منطقهاى خشكسالى هواشناسى

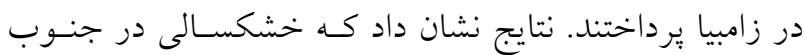
زامبيا از شمال آن شديدتر است. بر اساس آنجه آمد توسعه شـاخص خشكسـالى منطقـهاى

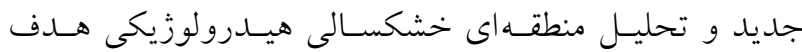
اصلى تحقيق حاضر را رقم مىزند. در اين راستا حوضه آبريـز

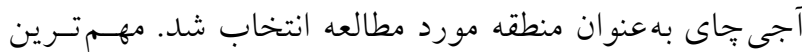




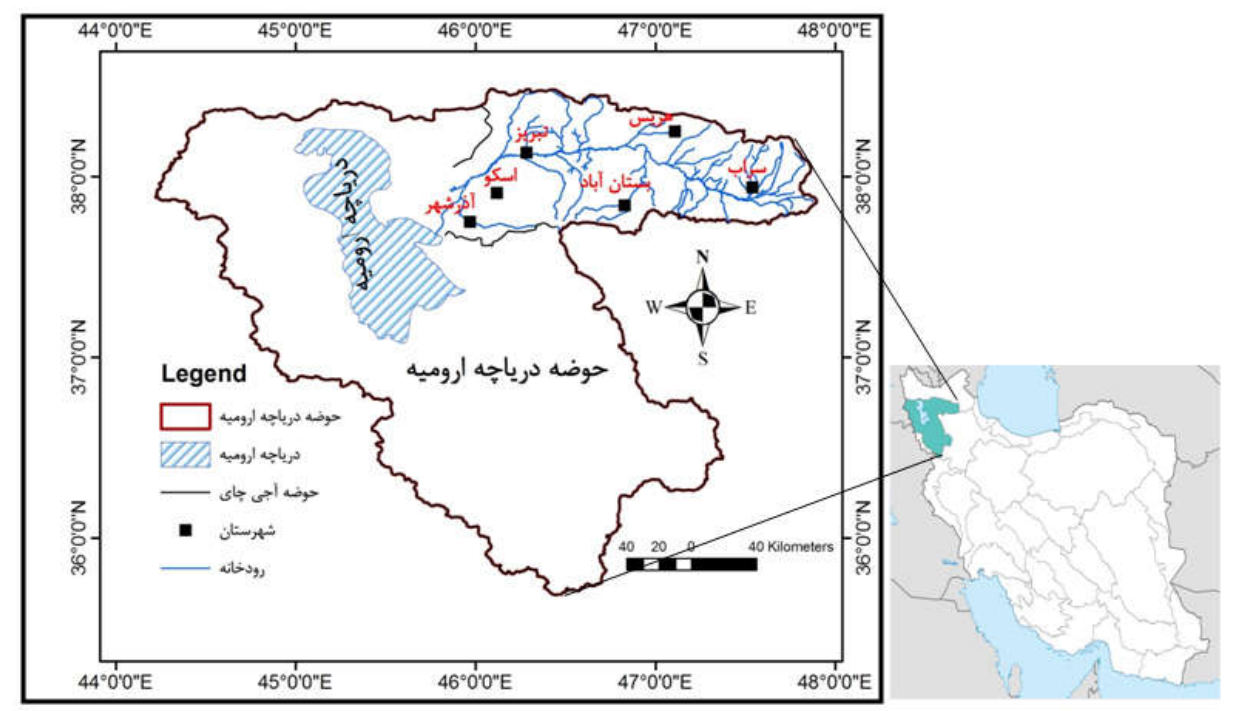

شكل ا. شمايى كلى از حوضه آبريز آجى جاى، شبكه رودخانها و شهرستانهاى واقع در آن

جدول 1. مشخصات ايستخاههاى آبسنجى مورد استفاده در تحقيق حاضر

\begin{tabular}{|c|c|c|c|c|c|}
\hline دوره آمارى & عرض جغرافيايى & طول جغر افيايى & رودخانه & كد ايستخاه & ايستخاه \\
\hline س & r & $\Psi V / V$ & آغميونجاى & M-ool & سهزاب \\
\hline سro|-1ra & rV/AY & $\forall \& / \Lambda 1$ & اوجان جّاى & $M-\circ \circ V$ & بستان آباد \\
\hline IrYq-1rq4 & rV/AD & $\varphi \varphi / \varphi \wedge$ & نهند ״جاى & rI-0ll & نهند \\
\hline 1 req-1rqu & $r V / q \Lambda$ & $\varphi 9 / 0 \Lambda$ & سعيد آباد & r & سعيد آباد \\
\hline$\| M r \Lambda-1 q_{0}$ & rN/l & $4 \& / 4$ & آجى جاى & ه & 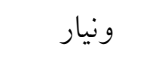 \\
\hline سrar-וra & MN/lo & 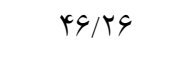 & كمناب جاى & rו-olv & آناخاتون \\
\hline سr|וrrm & rV/Ar & $r q / 4 r$ & ل ليقوان & r1-019 & ل ليقوان \\
\hline Iryq_וrqu & $r V / 91$ & $\varphi \varphi / 4 \wedge$ & ليقوان & $M I-0 Y I$ & هروى \\
\hline $\mid r k y-1$ rar & MN/\ & $49 / 11$ & سنيخ :جاى & $r ו-0 Y q$ & يِل سنيخ \\
\hline Irkg-1rar & $\mathrm{rV} / \Lambda \mathrm{D}$ & $\varphi \& / 0 r$ & سردرود & Mו-OM & زينجناب \\
\hline سr & rN/०r & $\Psi V / Q$ & تاجيار & זr-ומ & ميركوه حاجى \\
\hline rry & rV/VT & $48 / 1$ & كمبر جاى & M-०rV & قرمزيگل \\
\hline س & rN/0I & $49 / 00$ & آجى :جاى & M-opd & آخولا \\
\hline سr & $M N / Y Q$ & re/ro & كمانج جاى & rI-.0Q9 & كمانج \\
\hline & $\mathrm{rV} / 9 \mathrm{~V}$ & $40 / 91$ & آجى :جاى & 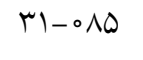 & سرين ديزج \\
\hline r & MN/०Q & $4</ 11$ & جـكه جاى & $m-109$ & مهربان \\
\hline س & MN/IS & $\forall \in / \wedge \mid$ & آجى جاى & II-11V & مركيد \\
\hline 1rqD-1rar & MN/lQ & $Y \varphi / 09$ & يازّجاى & $41-119$ & خواجه \\
\hline 1 rqd-1raq & $r \Lambda / r$ & $F V / I T$ & هر زورزجاى & rI-Orq & هرزورز \\
\hline
\end{tabular}




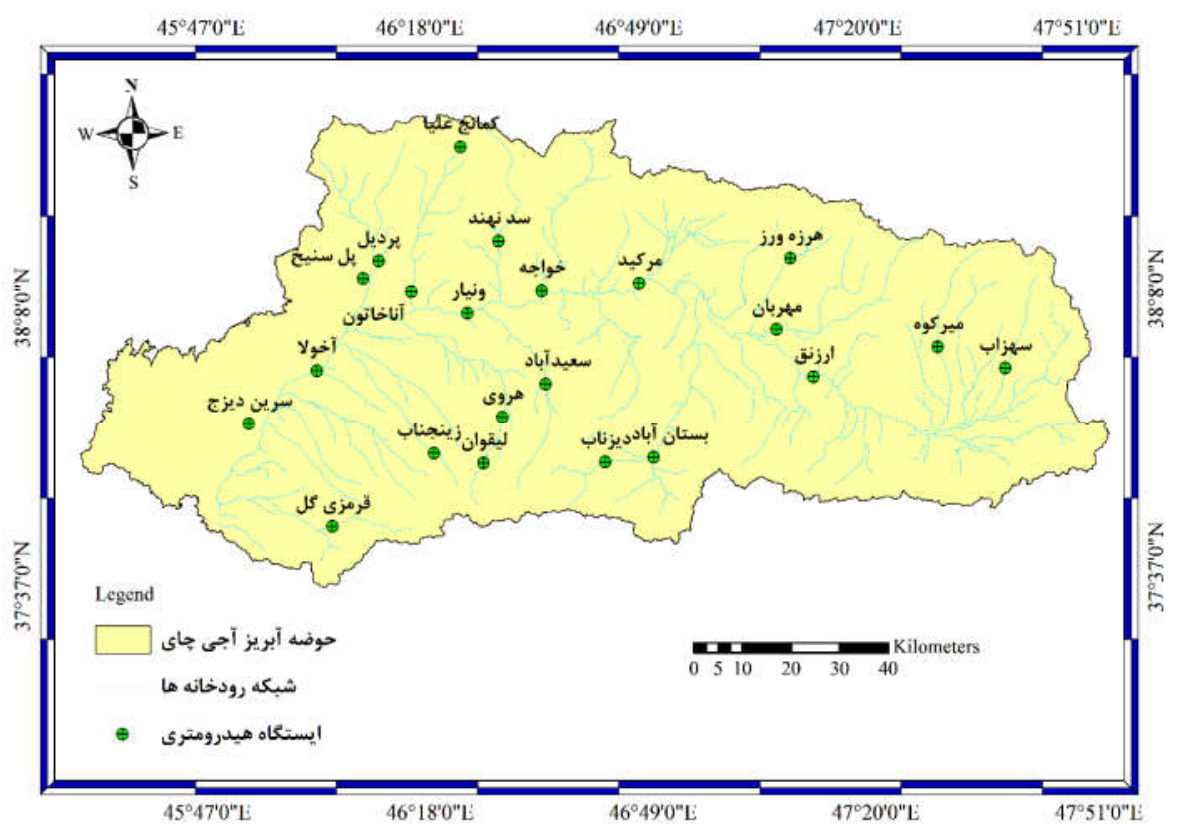

شكل r. موقعيت مكانى ايستكاههاى آبسنجى واقع در حوضه آجى جاى كه از آمار كافى برخوردار هستند.

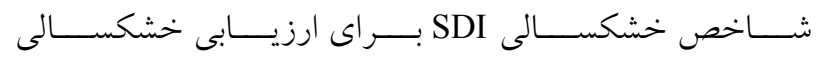

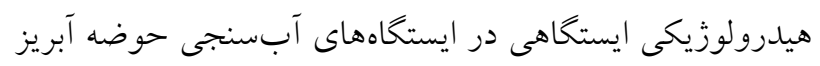

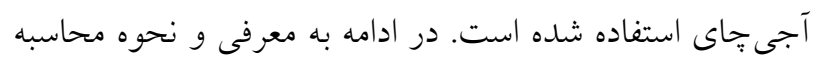

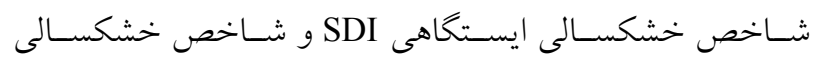

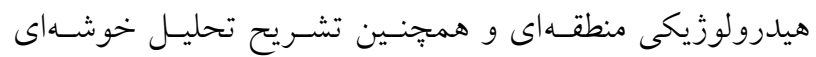
يرداخته خواهد شد.

شاخص خشكسالى جريان (SDI) קنانجه براى رودخانهاى دادهاى مربوط به سرى زمانى رواناب ماهانه براى N سال موجود باشد آنخاه شاخص SDI بـانـا اسـتفاده از روابط زير محاسبه مىشود (4 (ا):

$$
\mathrm{y}_{\mathrm{i}, \mathrm{j}}=\ln \left(\mathrm{Q}_{\mathrm{i}, \mathrm{j}}\right)
$$

$$
\mathrm{j}=1,2,3, \ldots, 12
$$

$\mathrm{i}=1,2,3, \ldots, \mathrm{N}$

$$
\operatorname{SDI}_{i, j}=\frac{y_{i, j}-\bar{y}_{j}}{s_{y, j}}
$$

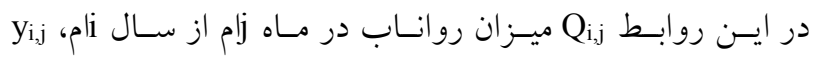

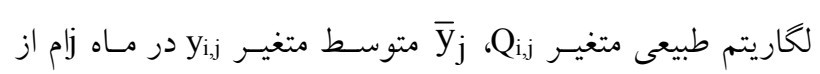

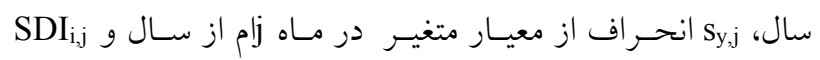

مراحل انجام تحقيق همانطور كه در قسمت مقدمه نيز بيان شد هدف تحقيق حاضر

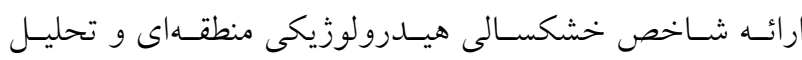

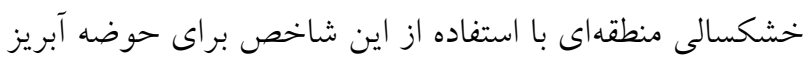

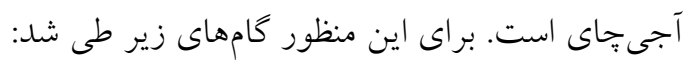

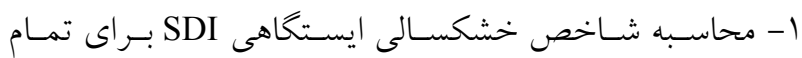
ايستخاههاى آبسنجى حوضه r- تحليل خوشهاى و تعيين مناطق همكن بهلحـاظ خشكسـالى ابلى

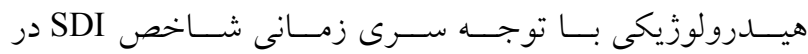

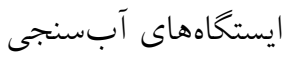
r- توسعه شاخص خشكسالى هيدرولوزيكى منطقهاى و تحليل

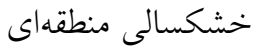

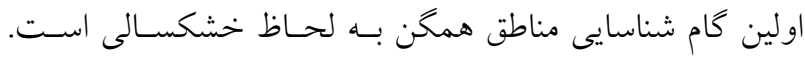

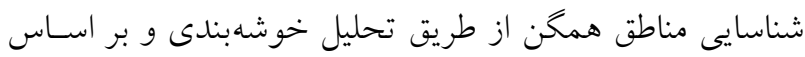

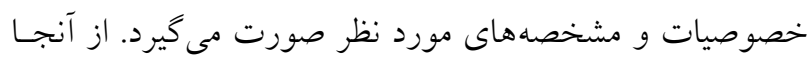

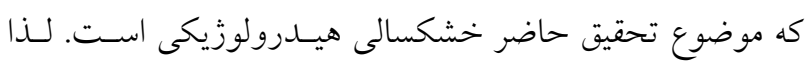

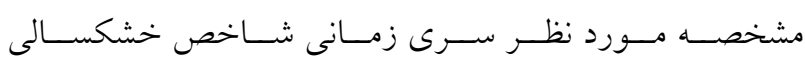

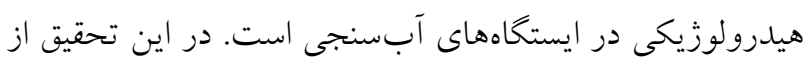


جدول Y. طبقهبندى شدت خشكسالى هيدرولوزيكى بر اساس شاخص SDI

\begin{tabular}{|c|c|}
\hline وضعيت خشكسالى & مقدار شاخص SDI \\
\hline ترسالى خيلى شديد & $\mathrm{SDI} \geq 2$ \\
\hline ترسالى شديد & $1.5 \leq \mathrm{SDI}<2$ \\
\hline ترسالى متوسط & $1 \leq \mathrm{SDI}<1.5$ \\
\hline ترسالى خفيف & $0 \leq \mathrm{SDI}<1$ \\
\hline خشكسالى خفيف & $-1 \leq \mathrm{SDI}<0$ \\
\hline خشكسالى متوسط & $-1.5 \leq \mathrm{SDI}<-1$ \\
\hline خشكسالى شديد & $-2 \leq \mathrm{SDI}<-1.5$ \\
\hline خشكسالى خيلى شديد & $\mathrm{SDI}<-2$ \\
\hline
\end{tabular}

در اين رابطه RDI

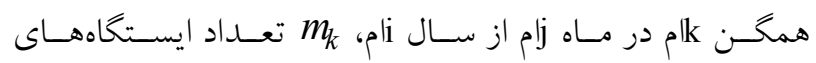

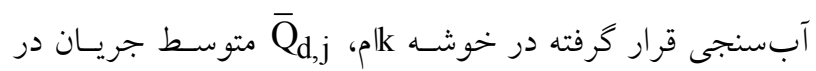
ايسـتخاه dام در مــاه لام و SDIi,j,d مقــدار شــاخص SDI در

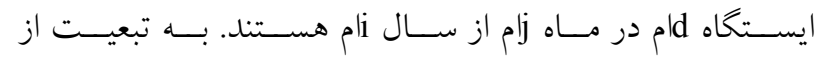
كلاسبندى شدت خشكسالى هيدرولوزيكى بر اساس شـاخص SDI مىتوان بر اساس شاخص RDI بهصورت جدول r دسـتهبندى

تحليل خوشهبندى

خوشه به كروهى از اشيا اطلاق مى شود كه نسبت به بقية اشسيا در خوشههاى ديخر مشابهت بيشترى با يكديخر دارند. بنابراين هدف از آناليز خوشهبندى، دستهبندى اشـيا بـر اسـاس ميـزان

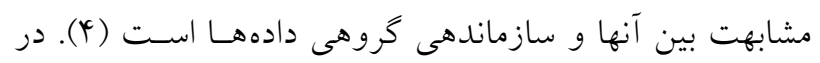
اين مطالعه، اشيا همان ايستخاههـاى آبســنجى حوضـهـ آبريـز

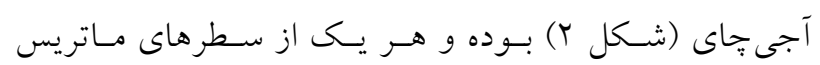
دادهها مربوط به سرى زمانى مقادير شاخص SDI در هر كدام از ايستخاههاى آبسنجى است. با توجه به اينكـه دوره زمـانى

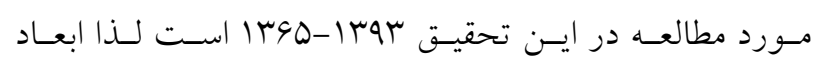

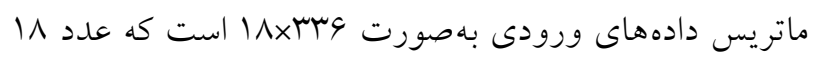

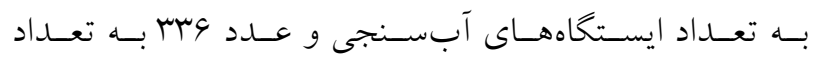

شاخص خشكسالى جريان در ماه زام از سال iأم هستند. جــول

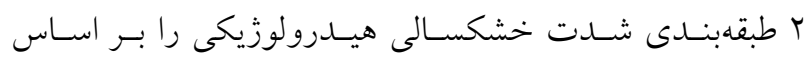
شاخص SDI نشان مى دهد.

شاخص خشكسالى منطقهاى هيدرولوزيكى (RDI) در اين تحقيق شاخص خشكسالى منطقهاى (RDI) جديدى بـر اساس شـاخص خشكسـالى ايستخاهى SDI توسـعه داده شــد. تفاوت شاخصهاى SDI و RDI در اين است كه شاخص SDI بـراى يـايش و تحليـل خشكسـالى هيـدرولوزيكى بـهـصـورت ايستخاهى (نقطهاى) بهكار مسىرود درحسالى كـه شـاخص RDI بهمنظور يايش منطقهاى خشكسالى توسعه داده شده اسـت و از اين لحاظ مى توانــ شاخصسى مناسـب بــراى تحليـل منطقـهاى خشكسالى در تصميم گيرىهاى كالان محسوب شود (11). يسس از آنكه سرى زمـانى خشكسـالى هيـدرولوزيكىى ايستخاهى بـا

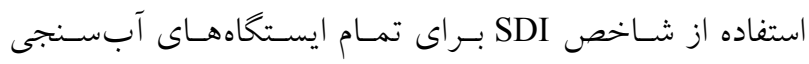
حوضه آبريز آجى جاى (شكل Y) محاسبه شـــ و بـا اسـتفاده از

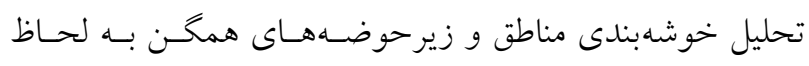
خشكسالى هيدرولوزيكى تعيين شد، شاخص RDI براى منطقـه همخن klo بهصورت زير تعريف مى شودئ

$$
\begin{aligned}
& \operatorname{RDI}_{\mathrm{i}, \mathrm{j}, \mathrm{k}}= \sum_{\mathrm{d}=1}^{\mathrm{m}_{\mathrm{k}}} \frac{\overline{\mathrm{Q}}_{\mathrm{d}, \mathrm{j}}}{\sum_{\mathrm{d}=1}^{\mathrm{m}_{\mathrm{k}}} \overline{\mathrm{Q}}_{\mathrm{d}, \mathrm{j}}} \mathrm{SDI}_{\mathrm{i}, \mathrm{j}, \mathrm{d}} \\
& \mathrm{i}=1,2,3, \ldots, \mathrm{N} \quad \mathrm{j}=1,2,3, \ldots, 12
\end{aligned}
$$


جدول r. طبقهبندى شدت خشكسالى هيدرولوزيكى منطقهاى بر اساس شاخص RDI

\begin{tabular}{|c|c|}
\hline وضعيت خشكسالى & مقدار شاخص RDI \\
\hline ترسالى خيلى شديد & $\mathrm{RDI} \geq 2$ \\
\hline ترسالى شديد & $1.5 \leq \mathrm{RDI}<2$ \\
\hline ترسالى متوسط & $1 \leq \mathrm{RDI}<1.5$ \\
\hline ترسالى خفيف & $0 \leq \mathrm{RDI}<1$ \\
\hline خشكسالى خفيف & $-1 \leq \mathrm{RDI}<0$ \\
\hline خشكسالى متوسط & $-1.5 \leq \mathrm{RDI}<-1$ \\
\hline خشكسالى شديد & $-2 \leq \mathrm{RDI}<-1.5$ \\
\hline خشكسالى خيلى شديد & $\mathrm{RDI}<-2$ \\
\hline
\end{tabular}

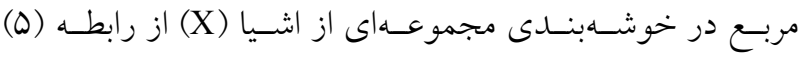
بادست مى آيد (r) (ب)

$$
\mathrm{J}(\mathrm{X} ; \mathrm{V})=\sum_{\mathrm{i}=1}^{\mathrm{c}} \sum_{\mathrm{k} \in \mathrm{i}}\left\|\mathrm{x}_{\mathrm{k}}^{(\mathrm{i})}-\mathrm{v}_{\mathrm{i}}\right\|^{2}
$$

در اين رابطه c تعداد خوشهها، فاصله شسيئ (i) فم از خوشـه أم از مبدأ مختصات بوده و لفاصله مركز جرم خوشـه iام از مبدأ مختصات است كه از رابطه (9) محاسبه مىشود: $\mathrm{v}_{\mathrm{i}}=\frac{\sum_{\mathrm{k}=1}^{\mathrm{N}_{\mathrm{i}}} \mathrm{x}_{\mathrm{k}}}{\mathrm{N}_{\mathrm{i}}}$

در اين رابطه، Ni تعداد مشاهدات در خوشهُ iام است.

\section{شاخص silhouette}

شـاخص silhouette از جملـه شـاخص هــايى اسـت كـه بـراى

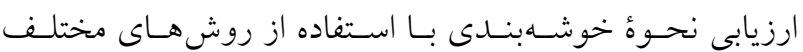
خوشهبندى، مورد استفاده قرار مى گيرد. اين شاخص با اسـتفاده از رابطه (V) محاسبه مىشود (م) (l):

$\mathrm{s}(\mathrm{i})=$ $\frac{b(i)-d i s t(i ; k)}{m a x(b(i), \operatorname{dist}(i ; k))}$

$$
b(i)=\min (\operatorname{dist}(i ; G), G \neq k)
$$

در اين رابطه، S(i) مقـدار شـاخص Silhouette بـراى واحـــ iام بوده و dist(i;k) متوسط فاصله واحد iام واقـع در خوشسه از
ماههاى واقع در دوره مورد مطالعه اشاره دارند. بــراى محاسـبه ميـزان مشـابهت بـين ايسـتخاههـا از فاصـله اقليدسى استفاده شــده اسـت كـهـ بــراى دو نقطـه بــا مختصـات V( $\left.v_{1}, v_{2}, \ldots, v_{p}\right)$ زير بهدست مى آيد (†):

$$
\mathrm{D}^{2}(\mathrm{U}, \mathrm{V})=\left(\mathrm{u}_{1}-\mathrm{v}_{1}\right)^{2}+\left(\mathrm{u}_{2}-\mathrm{v}_{2}\right)^{2}+\cdots+\left(\mathrm{u}_{\mathrm{p}}-\mathrm{v}_{\mathrm{p}}\right)^{2}
$$

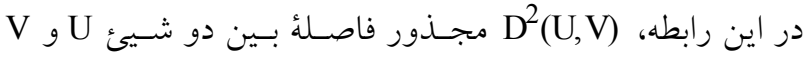

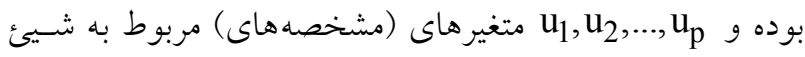

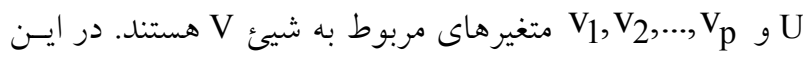
تحقيق v1 تا vo در واقع سرى زمانى مقادير شاخص SDI بـراى هر ايستخاه آبسنجى هستند.

\section{روش خوشهبندى K-means}

روش K-means يكى از روش هاى خوشهبندى تجزيهاى اسـت كه در تحقيق حاضر براى خوشهبندى ايستخاههاى آبسنجى به لحاظ رفتار خشكسالى آنها مورد استفاده قرار كرفته اسـت. ايسن روش با يك تقسيمبندى تصادفى اشيا شروع به كار مى كند و بـر اساس مشابهت آنها با مراكز خوشهها، كار اختصـاص دادن آنهـا را به خوشهها به انجام مسىرسـاند. ايـن حلقـه تــا زمـانى ادامـهـ مى يابد كه شرط همخر ايسى محقـق شـود (r). شـرط همخرايسى معمولاً رسيدن به ميزان حداقل خطـاى مجـذور اسـت. خطــاى 


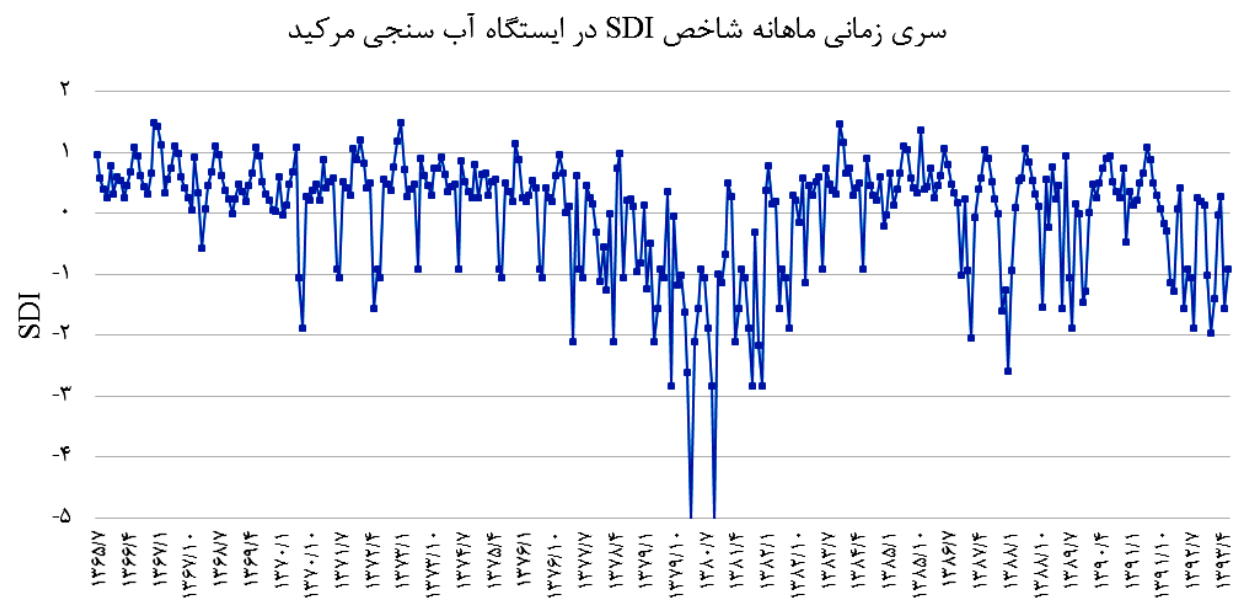

زمان (ماه)

شكل r. سرى زمانى ماهانه شاخص SDI در ايستخاه آبسنجى مركيد

پايش خشكسالى هيدرولوزيكى در حوضه آبريز آجى پاى

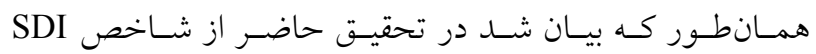

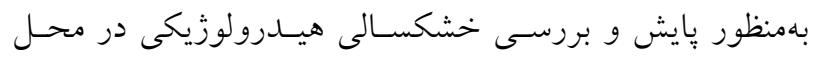
ايستكاههاى آبسنجى حوضه آبريـز آجسى جـاى استفاده شـده است. در شكل با بهعنوان نمونـه نمـودار سـرى زمـانى ماهانـه شاخص SDI در ايستخاه آبسـنجى مركيـــ بـــاى دوره زمـانى

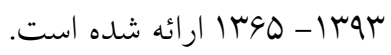

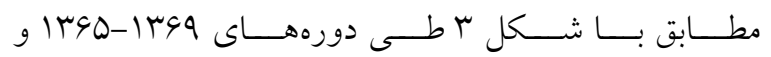

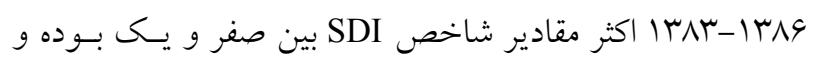

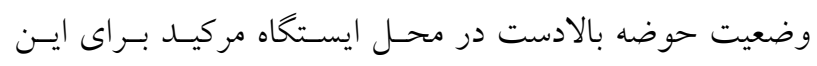

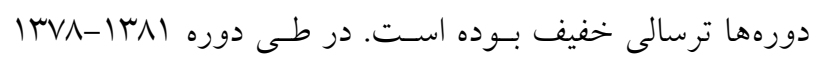

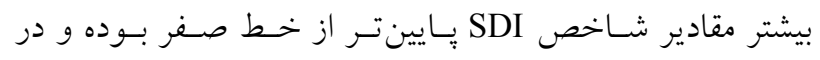

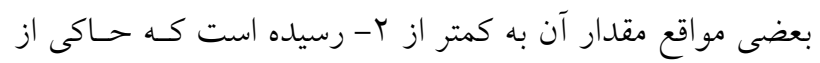
خشكسالى خيلى شـديد در طـى ايسن دوره اسـت. شــديدترين

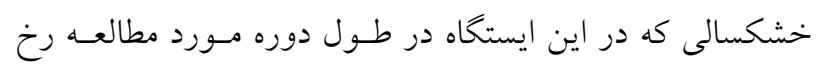

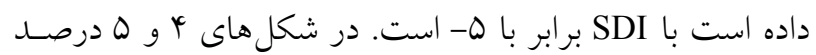

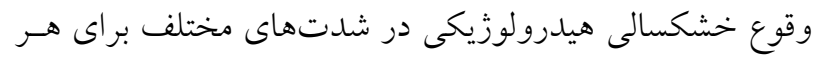

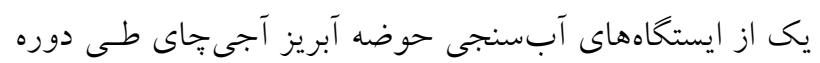

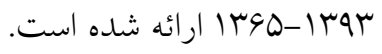

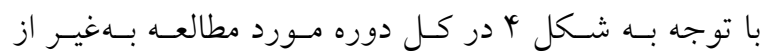

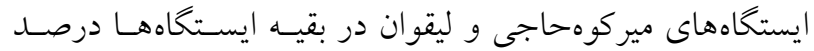

بقيه اعضاى واقع در همين خوشه است. مقادير اين شـاخص از

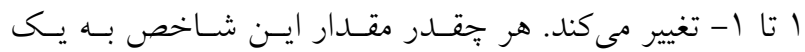

نزديك باشد خوشهبندى بهخوبى صورت كرفته است (م ا). در تحقيق حاضر تحليل خوشهبنـدى بـهروش K-means بـا استفاده از برنامـهنويسى در محسيط MATLAB انجـام كرفـت.

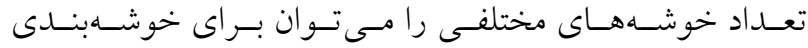

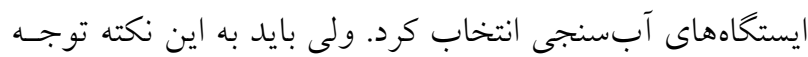

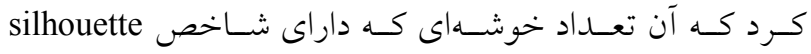
بيشـترى اسـت (نزديـك بــه يـك). در ايـن تحقيـق از تعـداد

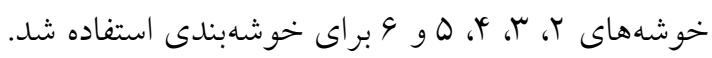
نتايج و بحث

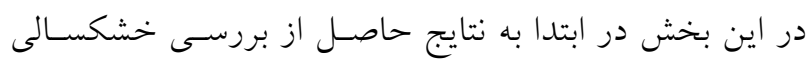

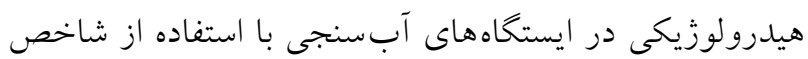
SDI

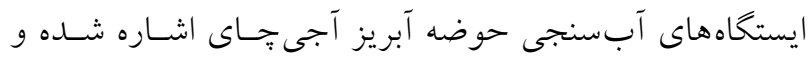

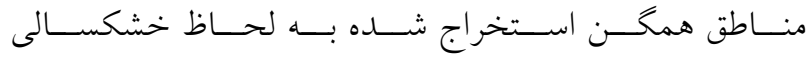

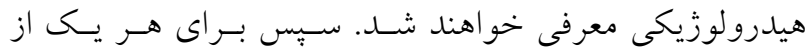

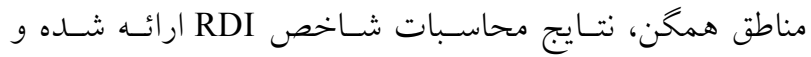
تحليل منطقهاى خشكسالى هيدرولوزيكى بر اسـاس شـاخص هن مذكور صورت خواهد كرفت. 


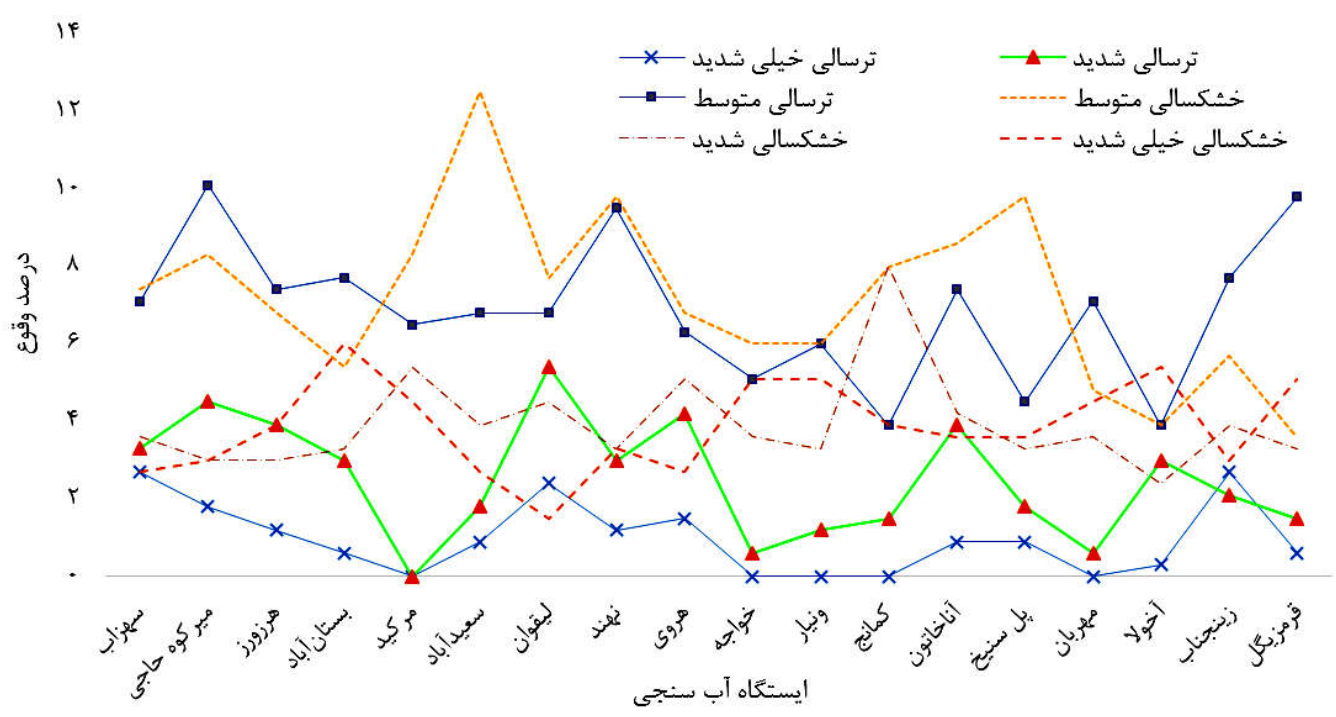

شكل ؟ا. درصد وقوع خشكسالى هيدرولوزيكى در شدتهاى مختلف براى هر يك از ايستخاهاى آبسنجى حوضه آجى جاى طى دوره rar|-

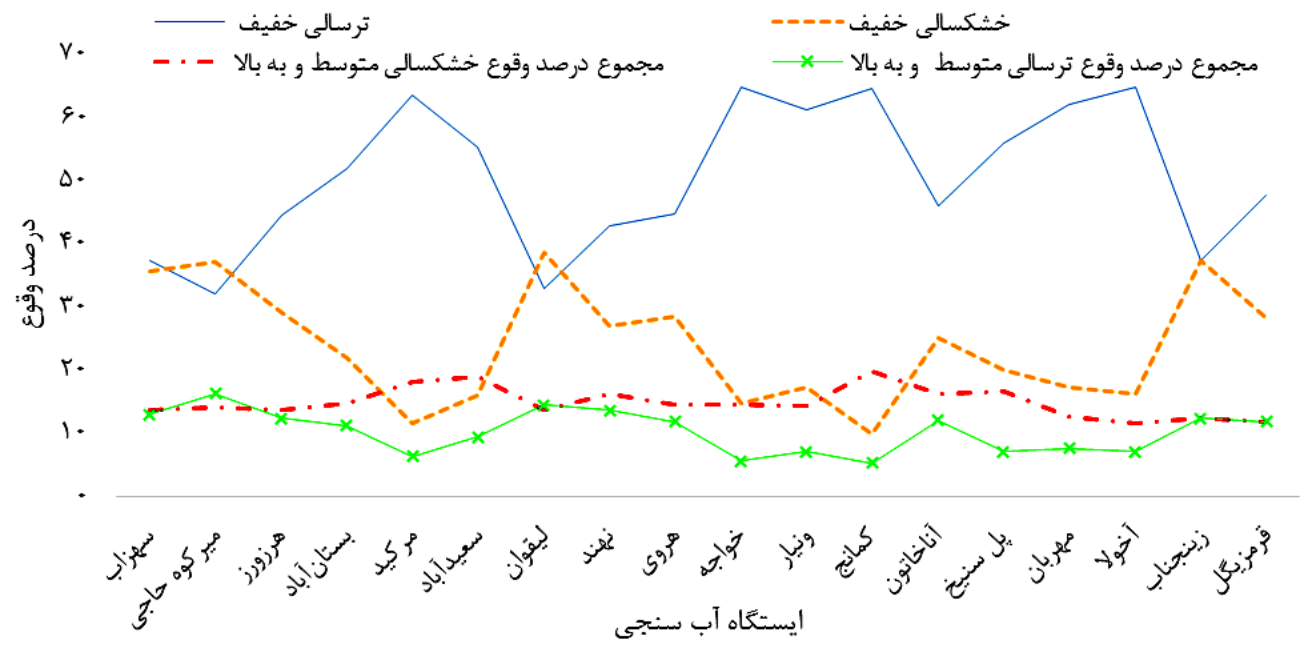

شكل ه. درصد وقوع خشكسالى و ترسالى خفيف هيدرولوزيكى، بههمراه مجموع وقوع خشكسالىها و ترسالى هاى هيدرولوزيكى

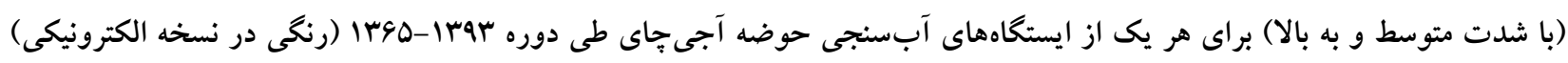

آجى جاى واقع شدند تعداد رخــادهاى خشكسـالى بـا شـدت

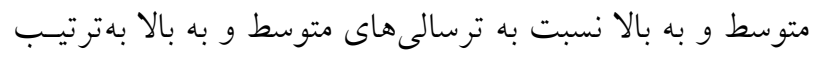

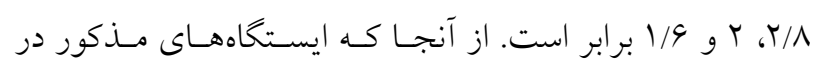

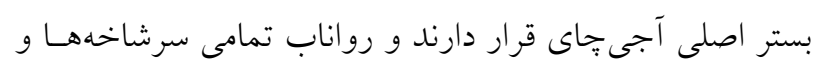

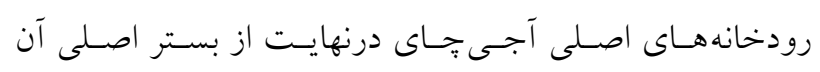

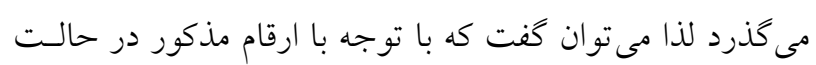

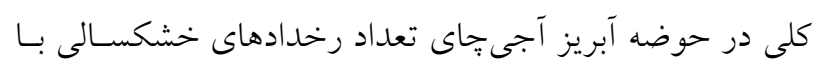

وقوع خشكسالى با شـــت متوسـط و بـهـ بـالا از درصــ وقـوع

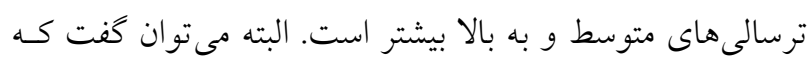

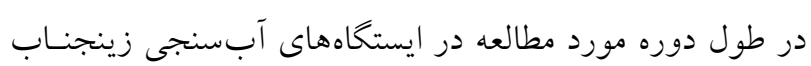

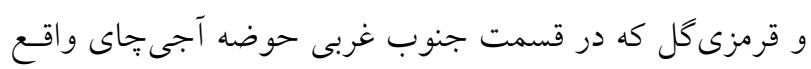

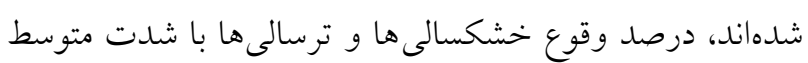

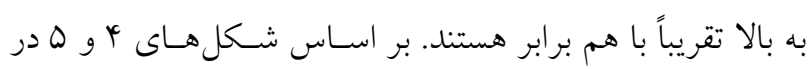

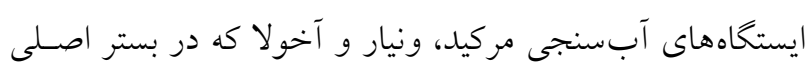


جدول f. نتايج خوشهبندى ايستخاهاى آبسنجى در حوضه آبريز آجى جاى بر اساس شاخص SDI

\begin{tabular}{|c|c|c|c|c|c|c|}
\hline \multicolumn{5}{|c|}{ تعداد خوشه } & \multirow{2}{*}{ كد ايستكاه } & \multirow{2}{*}{ نام ايستگاه } \\
\hline 4 & 0 & $r$ & $r$ & r & & \\
\hline$r$ & 1 & 1 & r & 1 & $r \mid-001$ & سهزاب \\
\hline$r$ & 0 & $r$ & r & 1 & rl-oov & بستان آباد \\
\hline 4 & 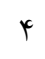 & r & 1 & r & $m 1-011$ & نهند \\
\hline r & 0 & $r$ & 1 & r & $r-0 \mid r$ & سعيد آباد \\
\hline$r$ & r & r & r & 1 & $M-010$ & ونيار \\
\hline 4 & r & r & 1 & r & MI-olv & آناخاتون \\
\hline r & 1 & 1 & r & r & $41-019$ & ليقوان \\
\hline$r$ & r & r & $r$ & 1 & $M I-0 Y$ & هروى ل مرو \\
\hline 0 & r & r & 1 & r & M-orq & بِل سنيخ \\
\hline 1 & 1 & 1 & r & r & $M I-\circ \mu$ & زينجناب \\
\hline$r$ & 0 & $r$ & $r$ & 1 & MI-orr & ميركوه حاجى \\
\hline 0 & 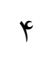 & r & 1 & r & $r$ rorV & قرمزيخل \\
\hline$r$ & r & r & r & 1 & $M I-040$ & آخولا \\
\hline 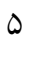 & 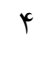 & r & 1 & r & $r 1-.09$ & كمانج \\
\hline r & r & $r$ & 1 & r & $m-1.109$ & مهربان \\
\hline$r$ & r & $r$ & r & 1 & $M-11 V$ & مركيد \\
\hline 9 & r & r & 1 & r & $41-119$ & خواجه \\
\hline r & r & r & r & 1 & $M I-Q T q$ & هرزورز \\
\hline
\end{tabular}

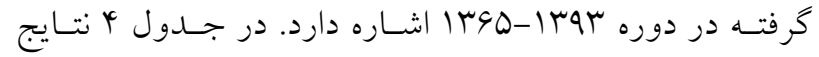
خوشهبندى ايستخاههاى آبسنجى بر اساس شـاخص SDI بـا

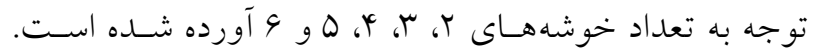

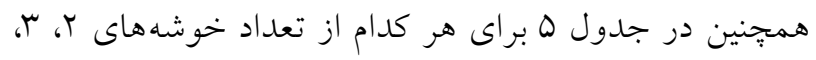

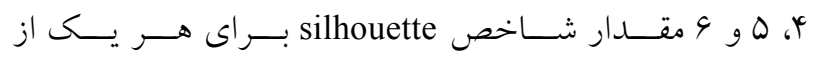
ايستخاههاى آب سنجى نشان داده شده است. همانطور كـه در

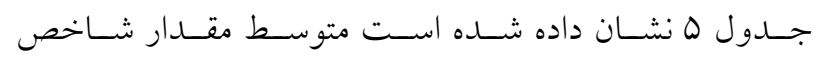
silhouette

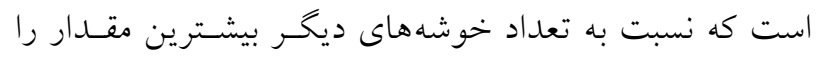

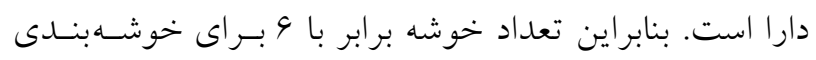
ايستخاههاى آبسنجى درنظر كرفته شد.

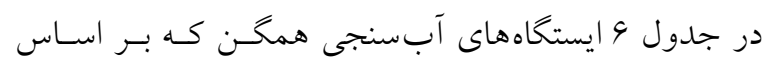
شاخص SDI خوشهبندى شدهاند نشان داده شده اسـت. مطابق
شدت متوسط و به بالا در مقايسه با ترسالىهـاى متوسط و بــه

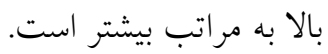

تعيين مناطق همخن به لحاظ خشكسـالى هيـدرولوزيكى در

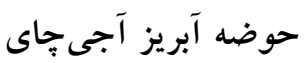
يّ إز محاسبه شاخص SDI بـراى هـر يـك از ايستخاههـاى

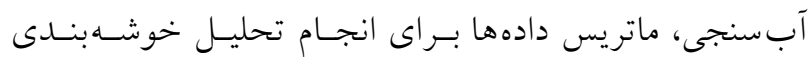
تشكيل شد. لازم به ذكر است كه هر رديف از ماتريس دادههـا

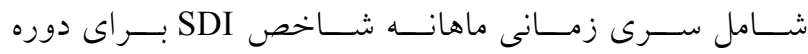

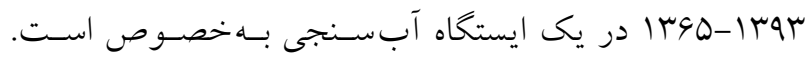

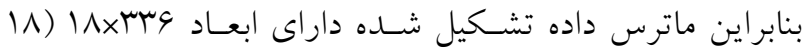

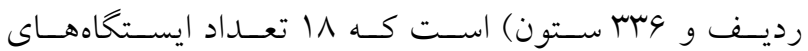
آبسنجى مورد مطالعه بوده و وبس بـهـ تعـداد مـاههـاى قـرار 
جدول ه. مقادير شاخص silhouette مربوط به خوشهبندى ايستخاهاى آبسنجى واقع در حوضه آبريز

آجى جاى بر اساس شاخص SDI

\begin{tabular}{|c|c|c|c|c|c|c|}
\hline \multicolumn{5}{|c|}{ تعداد خوشه } & \multirow{2}{*}{ كد ايستخاه } & \multirow{2}{*}{ نام ايستخاه } \\
\hline 9 & 0 & r & $\mu$ & r & & \\
\hline$-0 / 0 Y$ & $-0 / \circ V$ & $-0 / 0 V$ & $-0 / 0 \mathrm{~V}$ & $0 / 1 Y$ & M-ool & سهزاب \\
\hline$\circ / \Lambda$ & $-0 / 0 Y$ & $0 / \pi 1$ & $0 / r T$ & O/YT & MI-oov & بستان آباد \\
\hline$-0 / 0 Y$ & $0 / 0 Y$ & $-0 / 01$ & $-0 / 0 \mu$ & $-0 / 00$ & rו-0ll & نهند \\
\hline $0 / 09$ & $\circ \%$ & $0 / 09$ & $-0 / 09$ & $-0 / 0 V$ & $\mu$ & سعيد آباد \\
\hline $0 / 49$ & $0 / T V$ & $\circ / T V$ & $0 / 79$ & $\circ / \mu_{\circ}$ & $|-0| 0$ & ونيار \\
\hline$-0 / \circ 0$ & $0 / 01$ & $\circ / 0 \circ$ & $0 / 0 Y$ & $-0 / 01$ & M-0IV & آناخاتون \\
\hline$\circ / 10$ & $\% \circ \mathrm{V}$ & $\circ / 10$ & $\circ / 11$ & $-0 / 0 r$ & $r 1-019$ & ليقوان \\
\hline $0 / 19$ & $0 / 14$ & $\circ / 1 \mathrm{~V}$ & $0 / 19$ & $0 / 19$ & Mו-०Y & هروى \\
\hline r & $0 / 11$ & $0 / 09$ & $\% / \%$ & $-0 / 01$ & $r 1-\circ r_{q}$ & يل سنيخ \\
\hline $1 / 00$ & $\circ / \circ \Delta$ & $\circ / 00$ & $\circ \% \Delta$ & $-0 / 00$ & Mו-० & زينجناب \\
\hline $0 / 1 Y$ & $-0 / 09$ & $\circ / \Lambda$ & $\circ / r_{0}$ & $\circ / Y_{0}$ & rו-Orr & ميركوه حاجى \\
\hline $0 / 14$ & $\circ / \circ V$ & $0 / 09$ & $\% / \varphi^{k}$ & $0 / 0 Y$ & M-orV & قرمزيخل \\
\hline $0 / T V$ & $\circ / \Upsilon \wedge$ & $\circ / T V$ & $\circ / \mu$ & $0 / 7 q$ & MI-oto & آخولا \\
\hline $0 / 10$ & $0 / 09$ & $0 / 09$ & $0 / 09$ & $0 / 0 \psi^{4}$ & $M 1-\circ 09$ & كمانج \\
\hline$\circ / 0 \mu$ & $-0 / 0 \psi^{4}$ & $0 / 04$ & $\circ \% \circ$ & $-0 / 0 \mu$ & $m 1-109$ & مهربان \\
\hline $0 / 19$ & $0 / 14$ & $0 / 19$ & O/rY & $0 / T_{1}$ & $M-11 \mathrm{~V}$ & مركيد \\
\hline$-0 / 0 Y$ & $1 / 00$ & $-0 / \circ \psi^{r}$ & $-0 / 09$ & $-0 / 0 \wedge$ & $11-119$ & خواجه \\
\hline$\circ / T Q$ & $0 / 19$ & $\circ / \Gamma \Lambda$ & $\circ \mu \circ$ & $\circ / \mu_{0}$ & $r 1-0 r q$ & هرزورز \\
\hline $0 / 19$ & $0 / 1 Y$ & $\circ / 11$ & $\circ / 10$ & $0 / 09$ & silhouette & متوسط شا \\
\hline
\end{tabular}

جدول 9. خوشهبندى ايستخاههاى آبسنجى بر اساس شاخص SDI در حوضه آبريز آجى

\begin{tabular}{|c|c|c|c|c|c|}
\hline 4 & 0 & 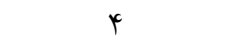 & $r$ & $r$ & 1 \\
\hline 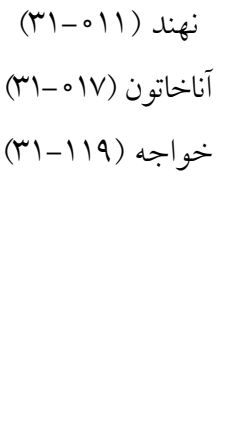 & 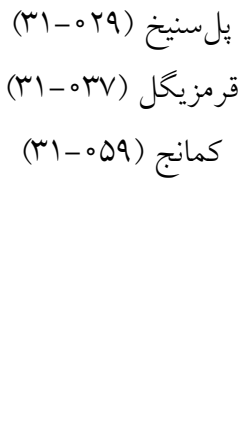 & 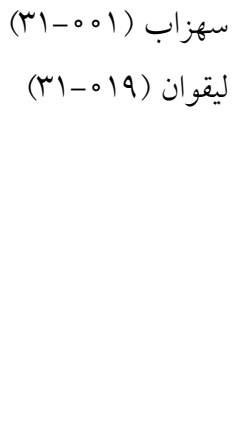 & 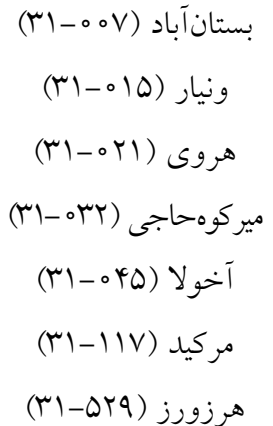 & 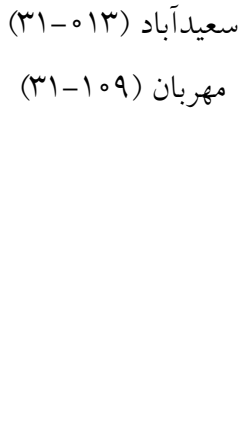 & زينجناب (الM-1M) \\
\hline
\end{tabular}

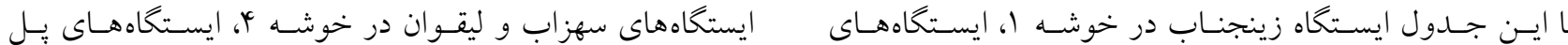

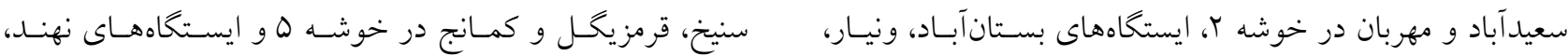

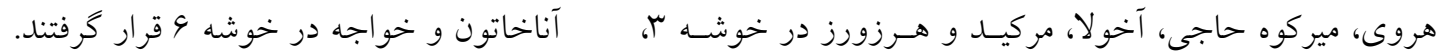




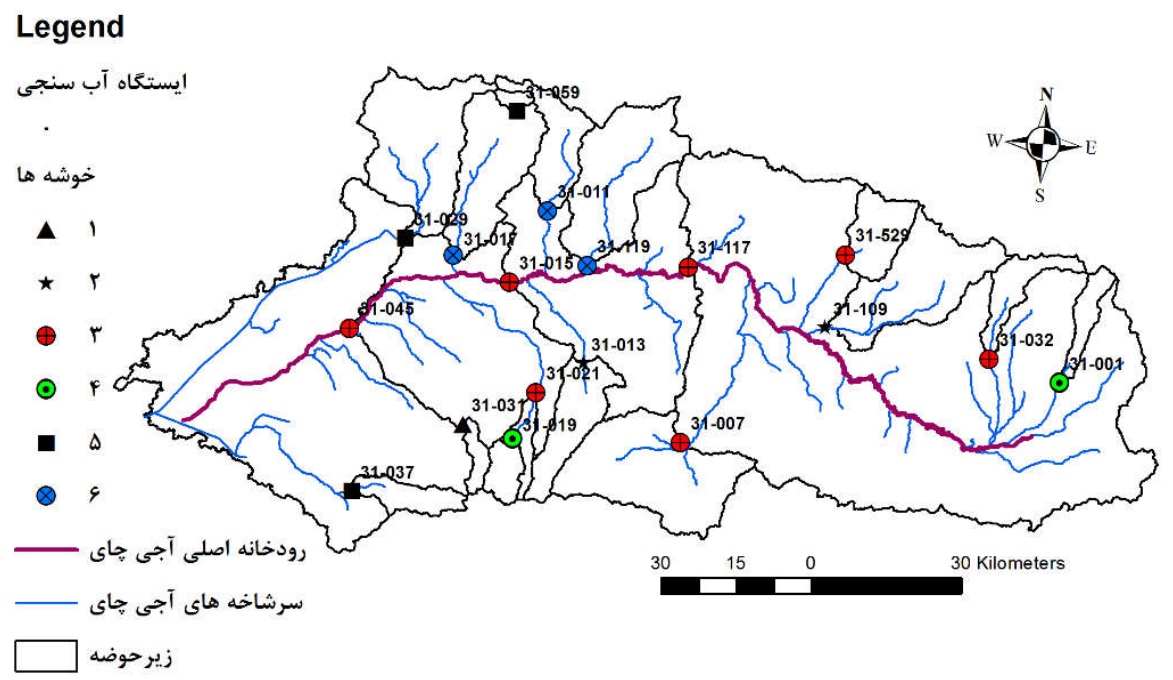

شكل 9. خوشهبندى ايستحاههاى آبسنجى بر اساس شاخص SDI در حوضه آبريز آجى پاى (رنكى در نسخه الكترونيكى)

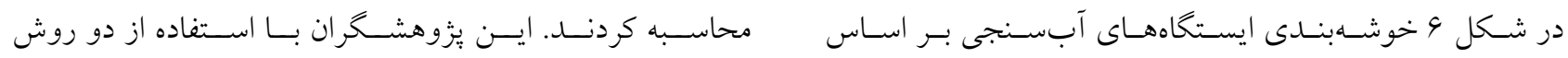

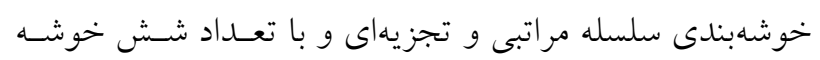
شاخص SDI در حوضه آبريز آجى بحاى نشان داده شده است.

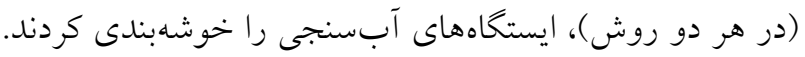

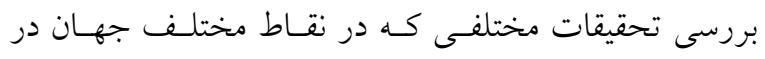

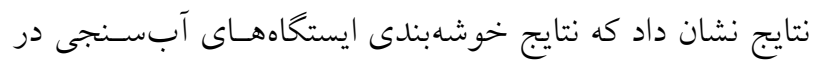

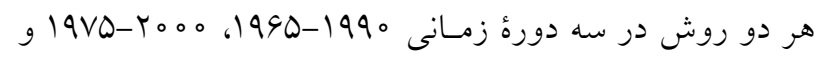

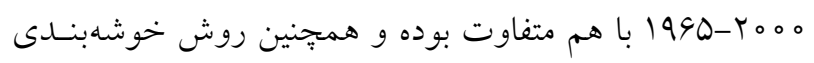

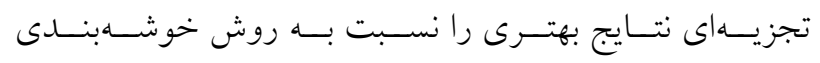

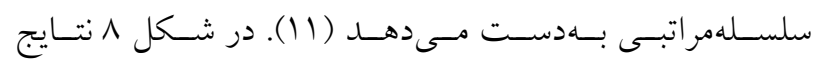
خوشهبندى ايستاههاى آبسنجى بهروش تجزيهاى براى دوره 1990-Yoo。 آبسنجى حوضه آجى جاى در تحقيق حاضر است.

ارزيابى خشكسالى هيدرولوزيكى منطقهاى در حوضه آبريسز

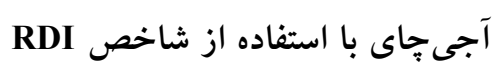

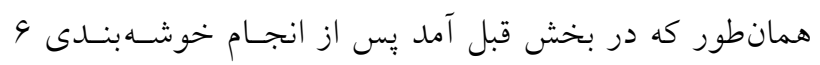

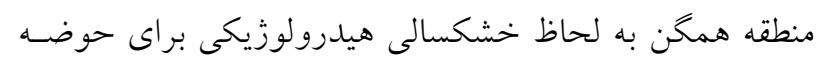

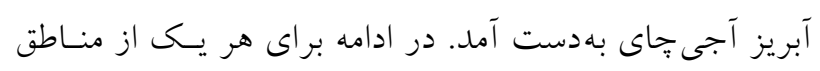

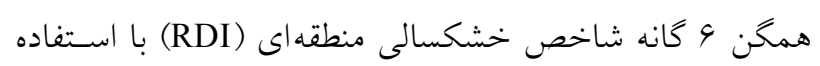

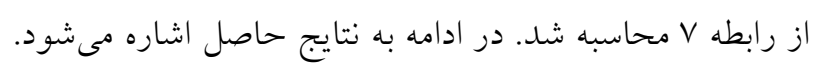

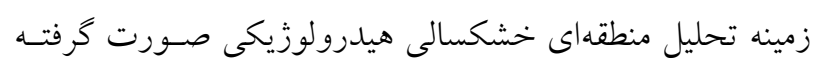
است نشان مىدهد كه اين تحقيقات نيز به نتايج مشابه بـا نتـايج

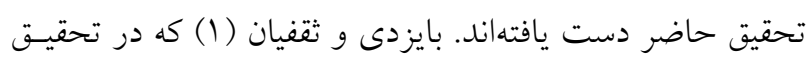

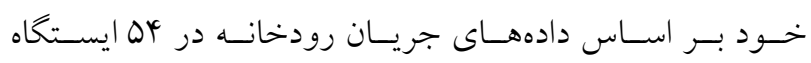

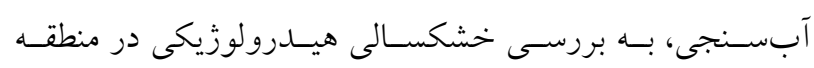

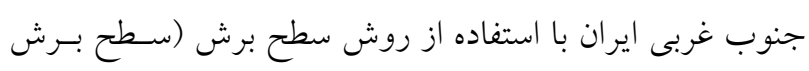

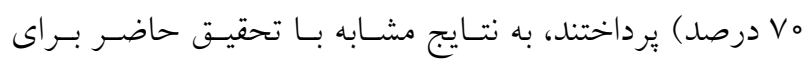
منطقه مورد مطالعه خود رسيدند. در اين تحقيـق بـا اسـتفاده از

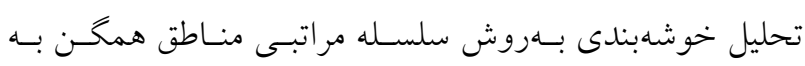
لحاظ خشكسالى هيدرولوزيكى تعيين شدند. نتايج تحقيـق آنها نشان داد سه منطقه همخگ در منطقه مورد مطالعسه وجـود دارد. در شكل V يُهنهبندى مناطق همخن ارائه شده است.

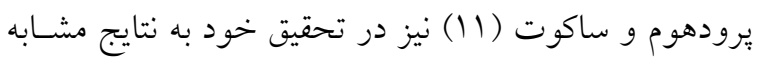

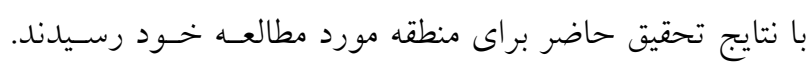

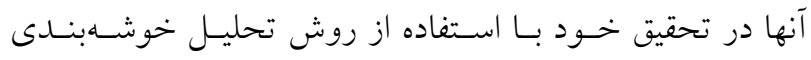

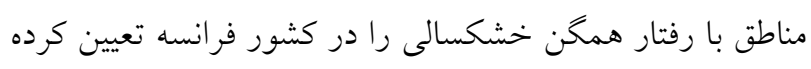

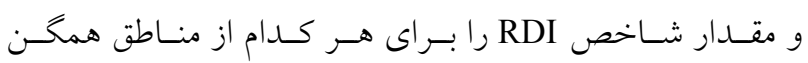




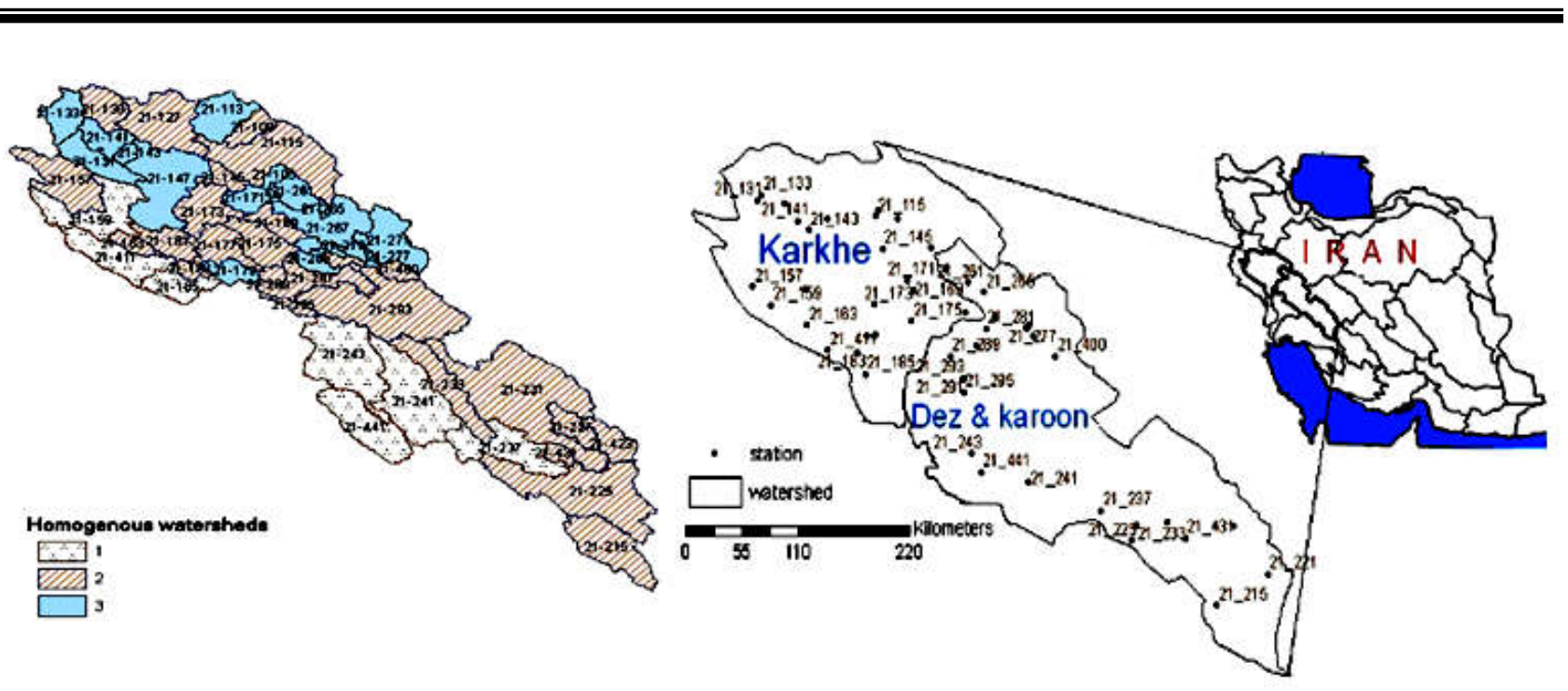

شكل V. براكنش مكانى ايستخاهاى آبسنجى در منطقه جنوب غرب ايران و مناطق همخن هيدرولوزيكى در آن (1)

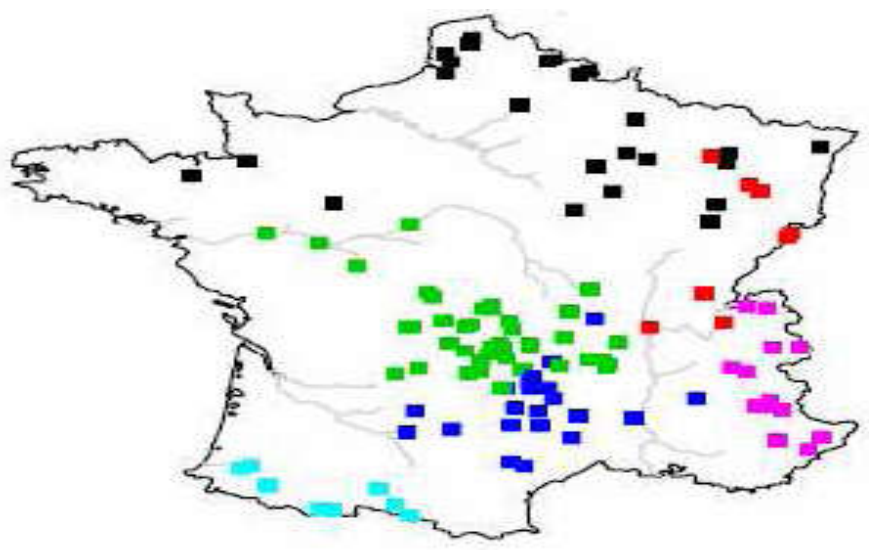

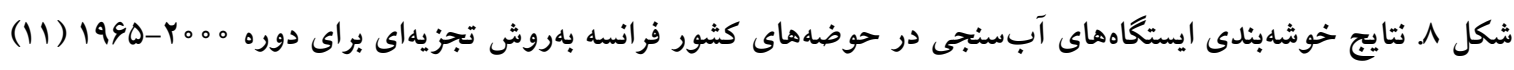
(رنحى در نسخه الكترونيكى)

با سطوح مختلف (بيشـتر ترسـالى خفيـف) رخ داده اسـت. ايسن

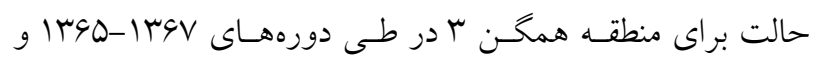
- IrqV

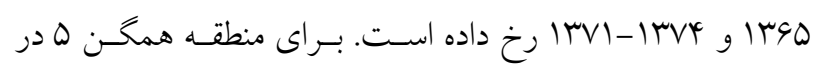

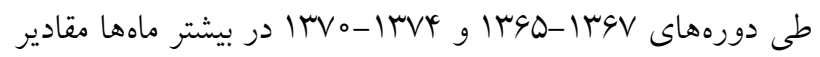
شاخص RDI بيشتر از صفر بوده و در طول دورههاى مذكور اكثر

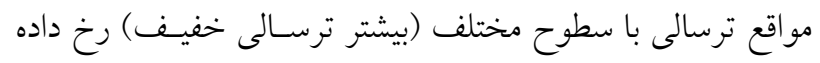

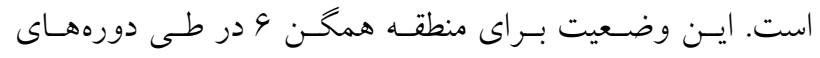
1 1

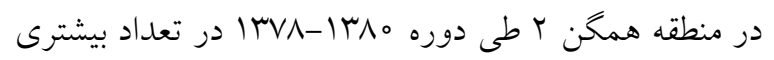

همانطور كه در جدول و آمــه اسـت منطقـه همخـن ا (خوشـهـ

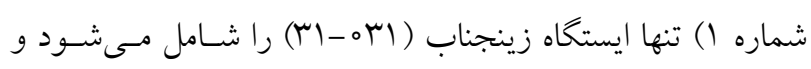

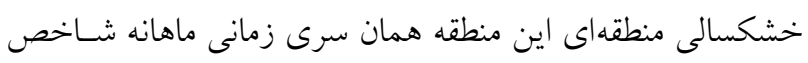

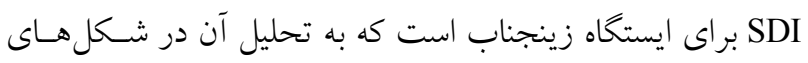

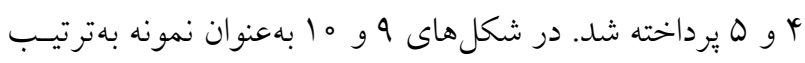

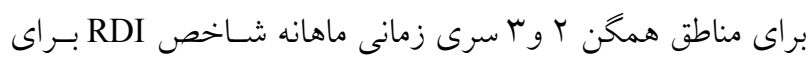

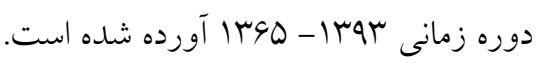

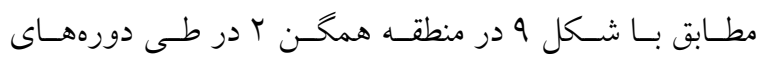

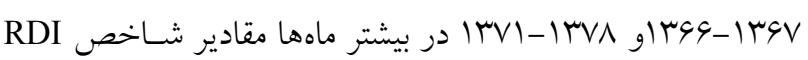
بيشتر از صفر بوده و در طول دورههاى مذكور اكثر مواقع ترسـالى 

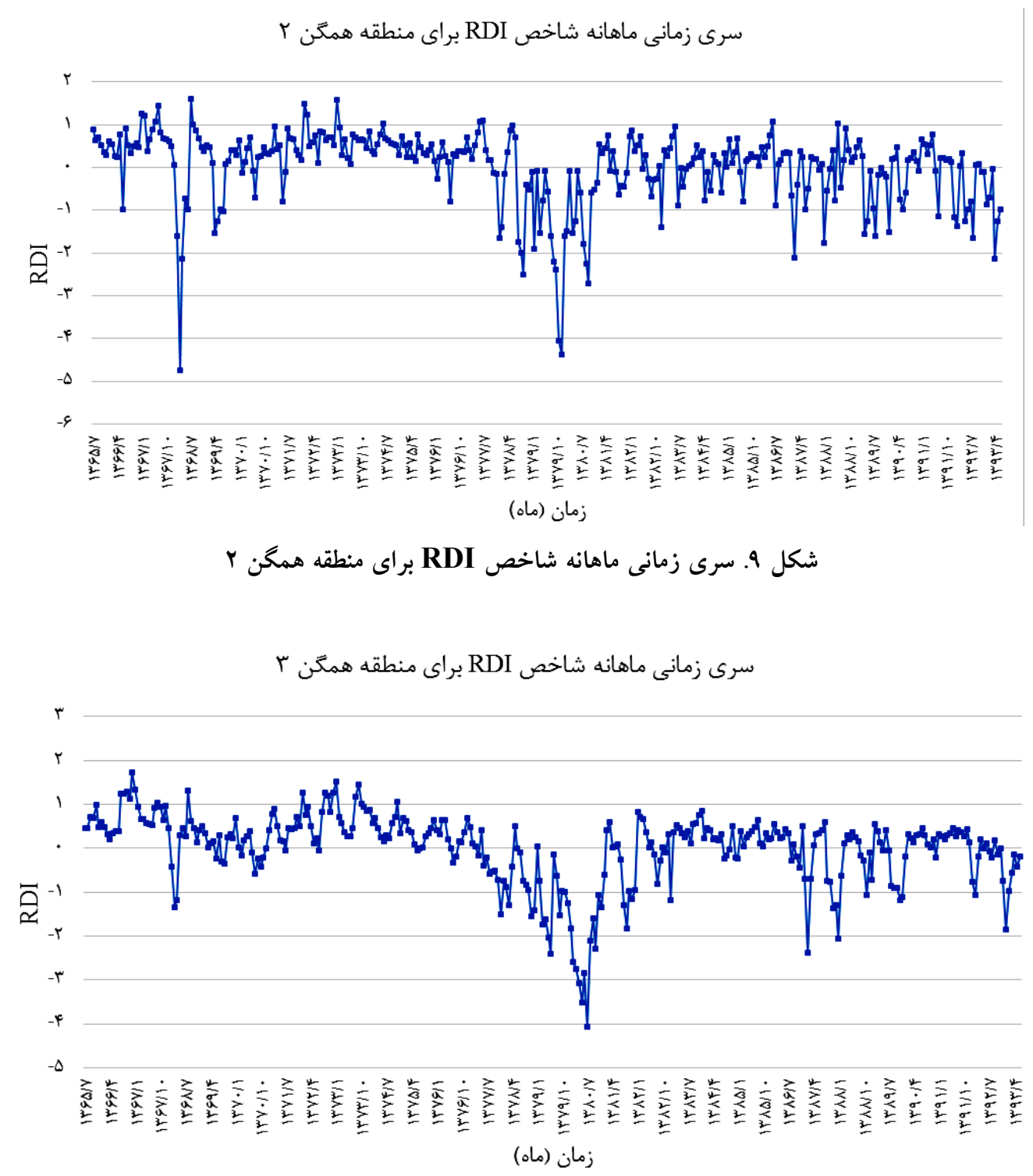

شكل • ا. سرى زمانى ماهانه شاخص RDI براى منطقه همگن مان ماه

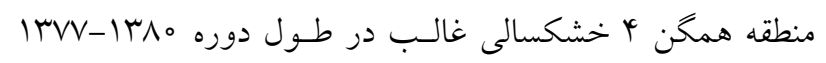
رخ داده است بهطورى كه در تعداد بيشترى از ماههاى اين دوره

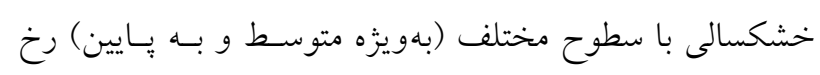

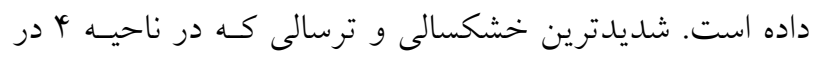

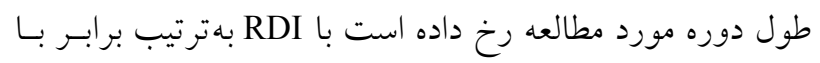

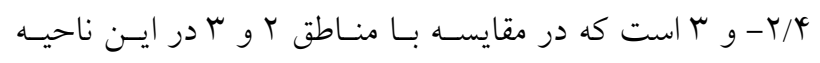

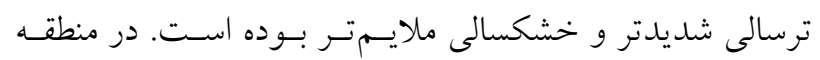

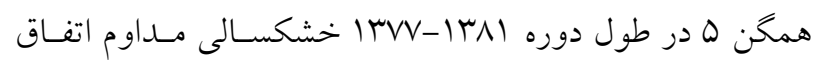

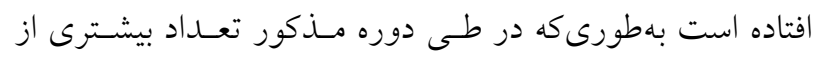

از ماهها خشكسالى با سطوح مختلف رخ داده است. شديدترين

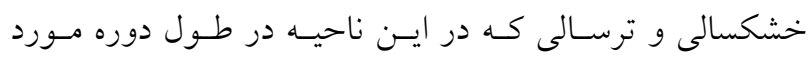

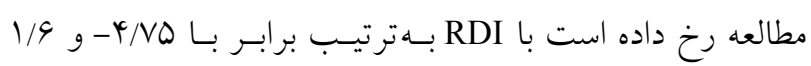

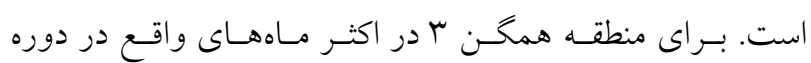
|rVV-|rN|

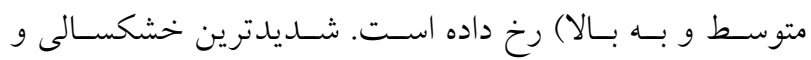
ترسالى كه در اين ناحيـه در طـول دوره مـورد مطالعـه رخ داده

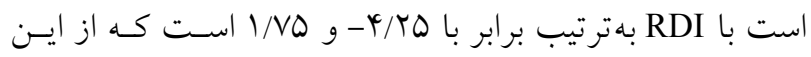

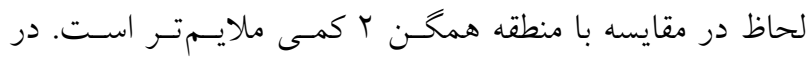




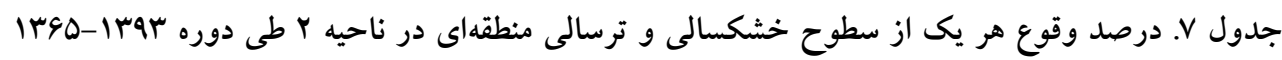

\begin{tabular}{|c|c|c|c|c|c|c|c|}
\hline 4 & 0 & $r$ & r & r & 1 & & \\
\hline$\circ / \pi$ & $\circ$ & $1 / r$ & $\circ$ & $\circ$ & $r / V$ & ترسالى خيلى شديد & $2 \leq \mathrm{RDI}$ \\
\hline$\circ / 9$ & $\circ / 9$ & $r$ & $0 / 9$ & $0 / 9$ & $r / l$ & ت ترسالى شديد & $1.5 \leq \mathrm{RDI}<2$ \\
\hline$\Delta / V$ & $\mathrm{~V} / \mathrm{I}$ & 9 & $\varphi / \Lambda$ & $r / 9$ & $\mathrm{~V} / \mathrm{V}$ & ترسالى متوسط & $1 \leq \mathrm{RDI}<1.5$ \\
\hline$\hat{i V / 9}$ & $0 \circ / 9$ & $r q / \mu$ & $90 / 1$ & $91 / \pi$ & $\mathrm{rV} / \mathrm{O}$ & ترسالى خفيف & $0 \leq \mathrm{RDI}<1$ \\
\hline 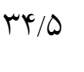 & $r 9 / 0$ & $r q / 9$ & $r M / r$ & $r Y / q$ & $\mathrm{rV} / \mathrm{d}$ & 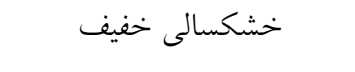 & $-1 \leq \mathrm{RDI}<0$ \\
\hline $9 \pi$ & $9 / 0$ & $V / V$ & $0 / 1$ & $r / 9$ & $\Delta / V$ & خشكسالى متوسط & $-1.5 \leq \mathrm{RDI}<-1$ \\
\hline$\varphi / r$ & $r / 9$ & $T / V$ & $T / V$ & $\varphi / \Lambda$ & $r / 9$ & خشكسالى شديد & $-2 \leq \mathrm{RDI}<-1.5$ \\
\hline$\circ / 9$ & $1 / \wedge$ & $\circ / 9$ & $r / 9$ & $r / \mu$ & r & خشكسالى خيلى شديد & $\mathrm{RDI}<-2$ \\
\hline $11 / 1$ & $11 / 9$ & 11 & $11 / 4$ & $11 / \mathrm{V}$ & $1 Y / 9$ & \multicolumn{2}{|c|}{ مجموع درصد وقوع خشكسالى (متوسط و به بالا) } \\
\hline $9 / 9$ & $\wedge$ & $10 / \pi$ & $\Delta /{ }^{\mathcal{C}}$ & $\varphi / r$ & $1 Y / 0$ & \multicolumn{2}{|c|}{ مجموع درصد وقوع ترسالى (متوسط و به بالا) } \\
\hline
\end{tabular}

درصد از مقادير شـاخص RDI بسين ا و إ ا-قـرار دارد كـه بـر

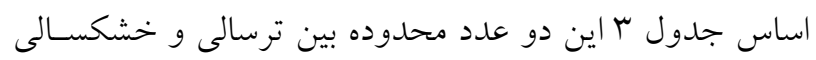
خفيف است. لازم به ذكر است كه مطابق با جدول V در منـاطق r، r و ه درصد وقوع ترسالى هاى خفيف بـه مراتسب بيشـتر از درصد وقوع خشكسالى هاى خفيف است اين موضسوع نشـان از آن دارد كه در اين منـاطق وضـعيت جريـان بيشـتر متمايـل بـهـ ترسالى خفيف بوده است. همانطور كه در جدول V نشان داده شده است طى دوره

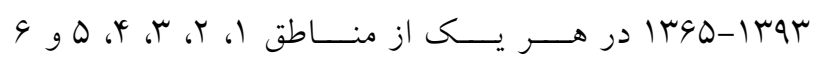
بـــترتيـب QV، س/N/ شاخص RDI بين ا و ا- قرار دارد كه بر اسـاس جـدول م اين دو عدد محدوده بين ترسالى و خشكسالى خفيف است.

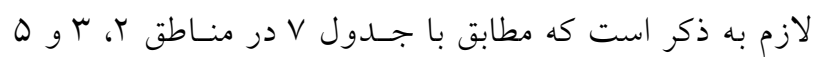
درصد وقوع ترسالى هاى خفيف بـهمراتـب بيشـتر از درصـد وقوع خشكسالى هاى خفيف است. اين موضـوع نشـان از آن دارد كه در اين منــاطق وضـعيت جريـان بيشـتر متمايـل بـهـ
ماهها خشكسالى با سطوح مختلف (بهويـزّه در سـطح متوسـط) رخ داده است. شديدترين خشكسالى و ترسالى كه در اين ناحيه در طول دوره مورد مطالعه رخ داده است با RDI بهترتيب برابـر

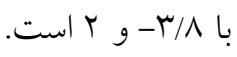
در منطقـــه همخــن وكماننـــــ ناحيـــه ه در طــول دوره |rN| شديدترين خشكسالى و ترسالى كه در اين ناحيه در طـول دوره

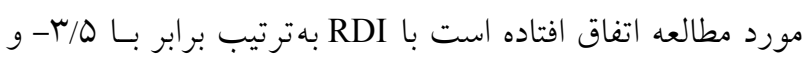
r است كه تقريباً با منطقه ه يكسان است. لازم ذكر است كه در

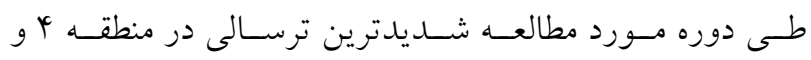
شديدترين خشكسالى در منطقـه r بــهوقـوع بيوسـته اسـت. در

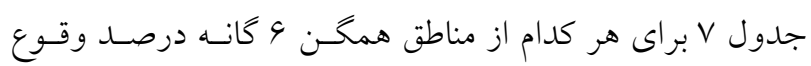
هريك از سـطوح خشكسـالى و ترسـالى در طسى دوره سوس اهوبا آورده شده است. همانطور كه در جــدول مـذكور نشـان داده شده است طى دوره سوب| -

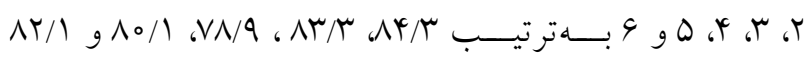


نتايج حاصل از تحقيق حاضر بهغيـر از ايستخاههـاى ليقـوان و

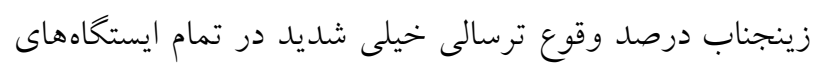

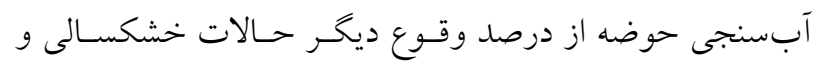

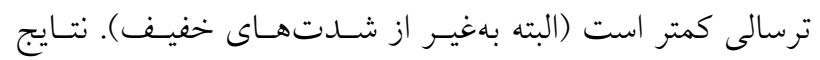

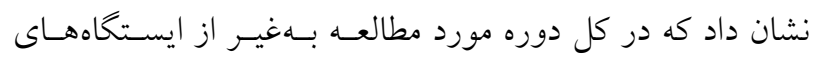

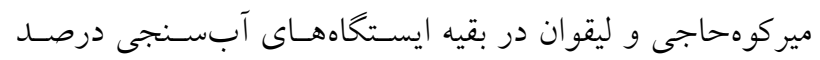

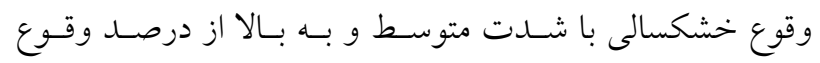

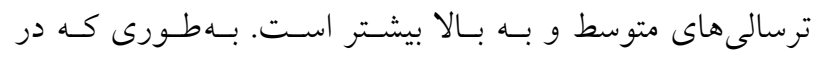

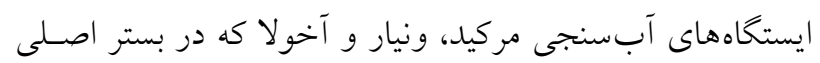

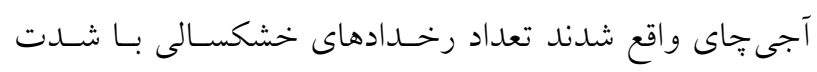

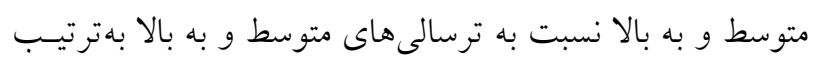

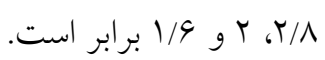

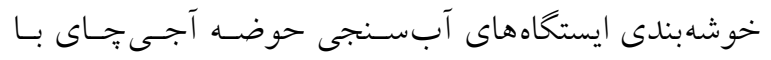

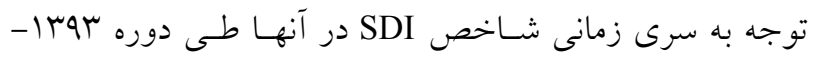

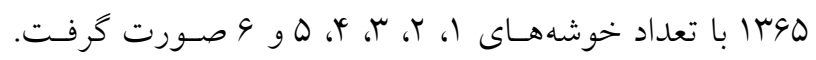

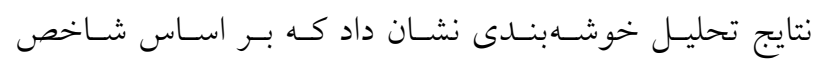

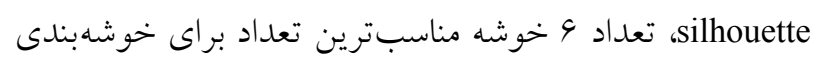

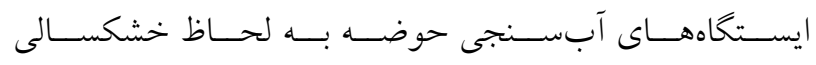

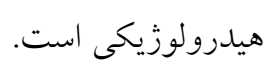

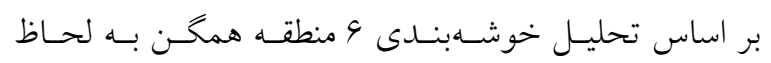

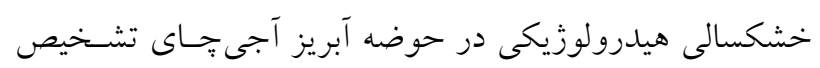

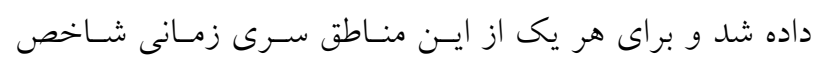

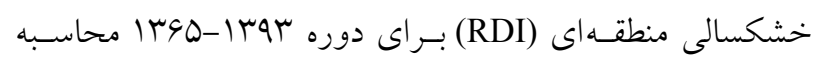

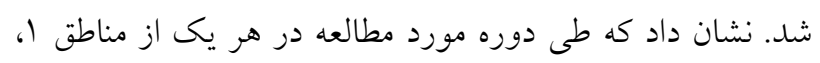

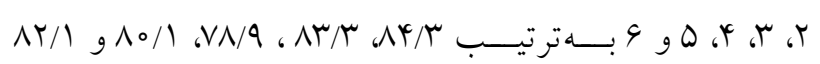

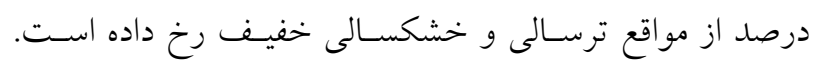

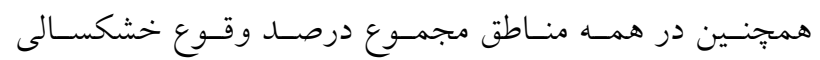

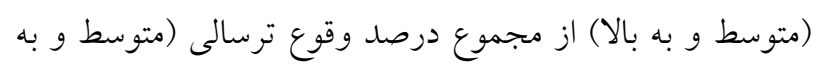

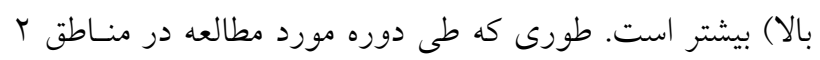

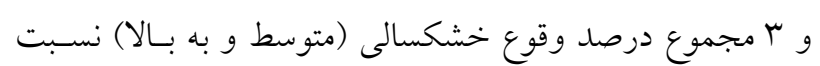

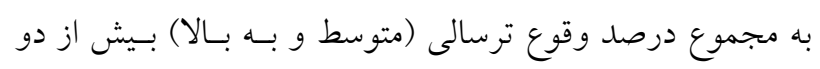
برابر است.
ترسالى خفيف بوده است. بر اساس جدول V مجموع درصد

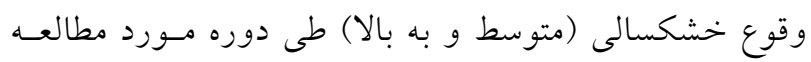

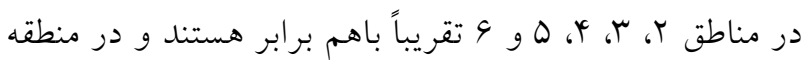

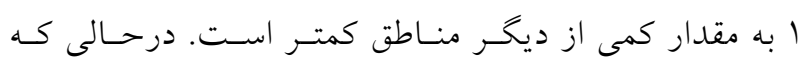

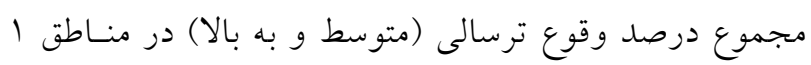

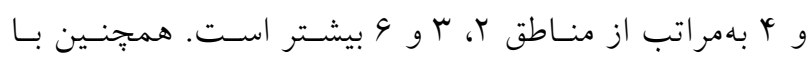

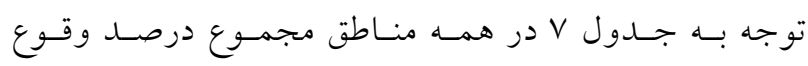

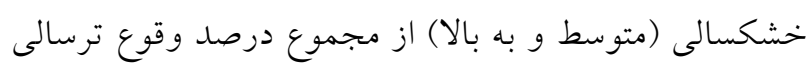

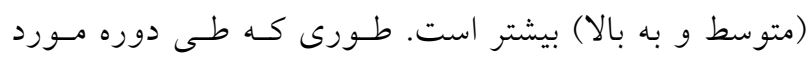

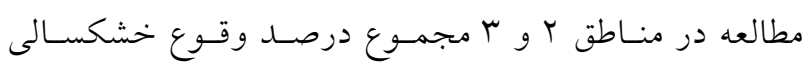

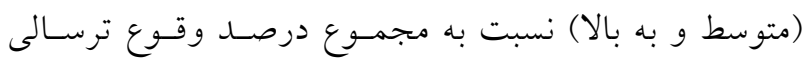

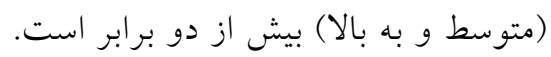

\section{نتيجه گيرى}

در تحقيـق حاضـر بـهـ بررسى و تحليـل منطقـهاى خشكســالى

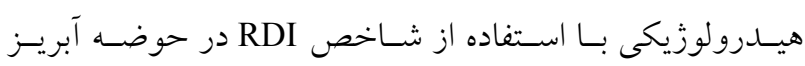

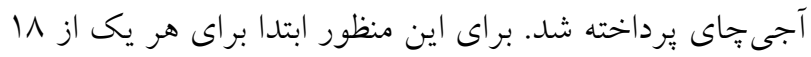

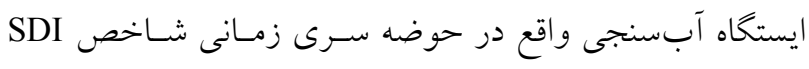

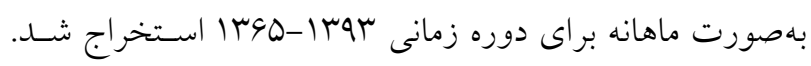

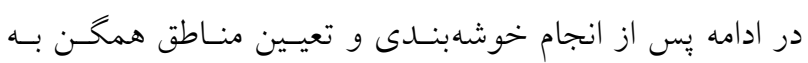

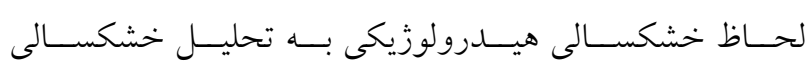

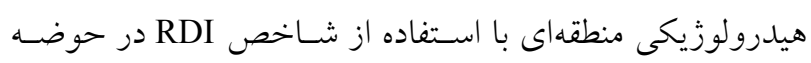

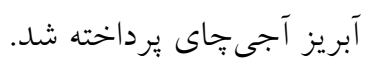

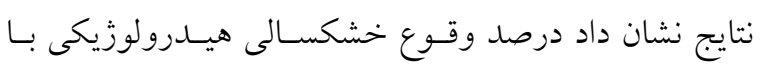

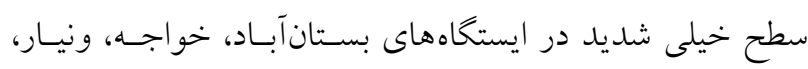

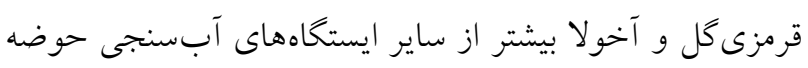

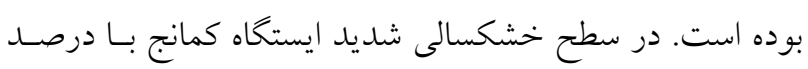

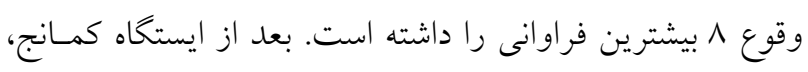

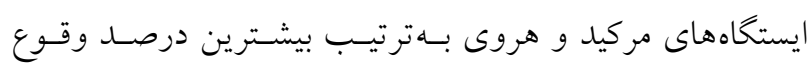

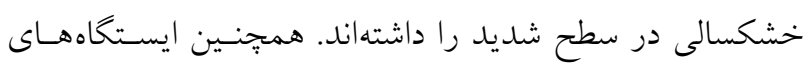

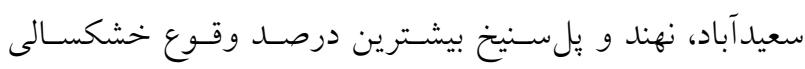

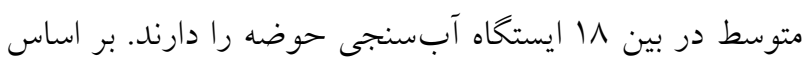


1. Byzedi, M., B. Saghafian, K. Mohammadi and M. Siosemarde. 2009. Regional Analysis of Streamflow Drought: A Case Study for Southwestern Iran. Journal of Environmental Earth Sciences 71: 2955-2972.

2. Dracup, J. A., K. S. Lee and E. G. Paulson. 1980. On the definition of droughts. Water Resources Research 16: $297-$ 302.

3. Han, J. and M. Kamber. 2006. Data Mining: Concepts and Techniques. 2nd Edition, Morgan Kaufmann Publishers, San Francisco.

4. Hoppner, F., F. Klawonn, R. Kruse and T. Runkler. 1999. Fuzzy Cluster Analysis: Methods for Classification, Data Analysis and Image Recognition. John Wiley \& Sons.

5. Islamian, S. S., M. Ghasemi and S. Soltani Ghord Faramarzi. 2012. Calculation and zoning of low flow indices and determination of hydrological drought periods (Case study: Karkheh watershed). Journal of Agricultural Science and Technology and Natural Resources, Soil and Water Sciences 59: 1-14. (In Farsi).

6. Islamian, S. S., R. Modarres and S. Soltani. 2005. Drought spatial clustering using standard precipitation index in Isfahan province. Technical Note, Quarterly Journal of Water and Sewerage 17: 75-72. (In Farsi).

7. Kaluba, P., K. M. J. Verbist, W. M. Cornelis, E. Van Ranst. 2017. Spatial mapping of drought in Zambia using regional frequency analysis. Journal of Hydrological Sciences 62: 1825-1839.

8. Mofidipour, A., V. Bardi Shaikh, M. Onagh and A. Sadudin. 2012. Investigating the Relationship between Meteorological and Hydrological Drought in Atrak Watershed. Journal of Basin Management 5: 16-26. (In Farsi).

9. Morid, S., V. Smakhtin and M. Moghaddasi. 2006. Comparison of seven meteorological indices for drought monitoring in Iran. Journal of Climatology 26: 971-985.

10. Pollard, K. and M. van der Laan. 2002. A Method to Identify Significant Clusters in Gene Expression Data. U.C. Berkeley Division of Biostatistics Working Paper Series.

11. Prudhomme, C. and E. Sauquet. 2007. Modelling a Regional Drought Index in France. Final Project Report ,Wallingford/Lyon, NERC/Centre for Ecology \& Hydrology \& Cemagref. (CEH Project Number: C02913).

12. Raziei, T. and G. Azizi. 2007. Regionalization of rainfall regime of the west of Iran using the principal components analysis and clustering methods. Technical Report, Water Resources Research, Third Year, Second Issue. (In Farsi).

13. Santos, J. F., I. Pulido-Calvo and M. M. Portela. 2010. Spatial and temporal variability of droughts in Portugal. Water Resources Research 46: W03503, doi:10.1029/2009WR008071.

14. Soleimani, S. and A. Bahremand. 2013. Hydrological drought analysis using SDI index in halilrud basin of Iran. The International Journal of Environmental Resources Research 1: 3.

15. Tabari, H., J. Nikbakht and P. Hosseinzadeh Talaee. 2013. Hydrological drought assessment in northwestern Iran based on streamflow drought index (SDI). Water Resources Management 27: 137-151.

16. Wilhite, D. A. 2000. Drough't as a Natural Hazard: Concepts and Definitions. Drought: A Global Assessment. London, Routledge, UK.

17. Zhang, Q., T. Qi, V. P. Singh, Y. D. Chen and M. Xiao. 2015. Regional Frequency Analysis of Droughts in China: A Multivariate Perspective. Water Resources Management 29(6): 1767-1787. 


\title{
Regional Analysis of Hydrological Drought in Ajichai Basin Using RDI Index
}

\author{
H. Ahmadzadeh ${ }^{1^{*}}$, A. Fakheri Fard ${ }^{1}$, M. A. Ghorbani ${ }^{1}$ and M. Tajrishy ${ }^{2}$
}

(Received: October 14-2020; Accepted: December 8-2020)

\begin{abstract}
In drought risk management, the regional analysis of drought is significant. In this paper, this important issue is investigated by presenting the new hydrological regional drought index (RDI). For this purpose, the Ajichai basin was selected as the study area. First, the time series of the streamflow drought index (SDI) was calculated for each of the hydrometric stations in the basin $\mathrm{f}$ regional analysis of hydrological drought. Then, to determine the homogeneous regions in terms of hydrological drought, the k-means method was used for clustering analysis. Based on the clustering results, 6 Homogeneous regions were identified in the basin. For each of these regions, the time series of the RDI index was calculated from 1365 to 1393 . The results showed that during the study period in each of the regions $1,2,3,4,5$, and 6, mild Wet and mild drought has occurred at 82.1, 80.1, 78.9, 83.3, and 84.3 percent of regions, respectively. Also, the total percentage of drought events (moderate and high) is higher than the total percentage of wet events (moderate and high) in all regions. So, during the study period, the total percentage of drought events (moderate and high) is more than twice the total percentage of wet events (moderate and high) in regions 2 and 3.
\end{abstract}

Keywords: Regional analysis of drought, SDI, Clustering, RDI, Homogeneous regions, Ajichai basin

1. Department of Water Engineering, Agricultural Faculty, Tabriz University, Tabriz, Iran.

2. Department of Water Engineering and Enviroment, Civil Engineering Faculty, Sharif University, Tehran, Iran.

*: Corresponding author, Email: hojatahmadzadeh6@gmail.com 